\title{
Experimental Investigation of Scour Hole Characteristics for Different Shapes of Piers Caused by Flood Hydrograph Succeeding Steady Flow
}

\author{
Aslı BOR ${ }^{1}$ \\ M. Şükrü GÜNEY²
}

\begin{abstract}
In this study, the scour depth and dimensions of the scour hole around different shaped piers for the cases of hydrographs succeeding steady flow were studied experimentally. The experiments were carried out by using circular, square, rectangular, lenticular and rectangular with trapezoidal nose to compare the various scour hole geometries at the same flow conditions. Numerous experiments were conducted in a rectangular flume (18.6 m long, 0.80 $\mathrm{m}$ wide and $0.75 \mathrm{~m}$ deep) with different triangular shaped hydrographs. The flume bed of 26 $\mathrm{cm}$ thickness consists of uniform graded material with $\mathrm{D}_{50}=1.68 \mathrm{~mm}$. The experiments were carried out in clear water conditions. The temporal variations of the equilibrium scour depths in front of the pier and the scour hole dimensions were recorded by two different cameras. The equilibrium scour depths at lateral sides and downstream of the piers were also measured. Regression analysis was performed in order to derive empirical relations to predict temporal variations of the scour depth in the case of unsteady flow. The shape factor values were also investigated based on the experimental findings and the obtained values were compared to those available in literature. The performance of the obtained empirical relation for circular pier was tested by using limited experimental data available in the literature. The smallest scour hole was observed for the rectangular with trapezoidal noses pier. The increase in the scour hole dimensions for other cross-sections was in the following order: rectangular with circular noses, circular, square and rectangular piers.
\end{abstract}

Keywords: Unsteady flow, local scour, scour hole, pier, shape coefficient.

\section{INTRODUCTION}

Bridges are an important part of transportation system which carry people and vehicles

Note:

- This paper has been received on July 22, 2019 and accepted for publication by the Editorial Board on December 6, 2019.

- Discussions on this paper will be accepted by May 31, 2021.

- https://doi.org/10.18400/tekderg.595126

1 Izmir University of Economics, Department of Civil Engineering, İzmir, Turkey - asli.turkben@ieu.edu.tr https://orcid.org/0000-0002-1679-5130

2 Izmir University of Economics, Department of Civil Engineering, İzmir, Turkey -sukru.guney@ieu.edu.tr https://orcid.org/0000-0003-1441-4784 
across. They are subjected to dynamic loads (wind, earthquake, flood ...etc.) more than other transportation structures. Bridge failures bring economic problems nationwide and cause tragic results. The relevant studies show that governments spend millions of dollars to prevent scour related to bridge damages [1].

The scour hole has been widely studied and various empirical equations have been developed over time by researchers [2-21]. These empirical equations are based on the experiments performed under different conditions. [22] showed that the dimensionless scour hole length and width depend on flow shallowness $(\mathrm{h} / \mathrm{b})$ for different shape of piers and presented relevant empirical relations. [15] carried out an experimental study to observe the temporal variations of the scour depth and contours around vertical wall and wing wall abutments. He developed a semi empirical model to determine dimensionless scour hole length and width depending on flow shallowness parameter. In the scope of his thesis, [16] studied the scour hole geometries in the case of circular and square piers under steady flow conditions. He proposed an equation for the scour hole volume in terms of the flow depth. [9] suggested an equation involving the flow shallowness in order to calculate the top width of scour holes. [23] carried out experiments with different shape of piers and they observed that all the equilibrium dimensionless parameters depend on the characteristic pier width.

In the literature, there are limited studies about non-circular piers. Although there are many works on local scour around bridge piers aiming to clarify the nonlinear relationship between sediment and flow, only few studies have been performed to interrelate the scour hole geometries and flow characteristics in the case of different types of pier shapes and under unsteady flow conditions.

[24] was the first researcher who used different shapes of the pier in his experiments. He proposed that local changes in flow caused by bridge piers or other obstructions influence the scour depth around the piers and he observed that the maximum scour depth occurred around the rectangular pier. [2] studied time and velocity effects on the clear water and live bed local scouring at bridge piers. They also carried out studies with different pier diameters, shapes, grain sizes and water depths. They showed that the maximum scour depth oscillated around the average depth. [4] studied time dependent scour depth variation both in clear water and live bed conditions by using circular piers. Their experiments aimed to show the effects of the different pier geometry, sediment and flow properties on the scour time. They allowed scour to occur around six-inch circular pier for desired depth and measured velocity distributions with a small Pitot tube in uniform bed materials. They found three types of vortex systems, namely trailing, horseshoe, and wake and explained them in detail. They showed that the geometry of the structure is important in determining the strength of the vortex system. In addition, they developed an empirical equation involving the pier diameter, average velocity and upstream water depth. [25] indicated that [4] study was based on narrow range of flow and sediment conditions, so it was not suitable for practical applications. The study of [4] had a single time scale, however, scour time histories indicate generally multiple time scales. [26] conducted a series of live bed scour experiments with different diameter of piers. They compared their experimental findings with those available in the related literature. They observed that stagnation pressure causes shear layers generated at the surface near the sediment bed. They also found that wake vortices behind the pier were dissipated as they moved downstream, the wake vortices being usually recognized from the small scale eddies. [16] studied different pier shapes with different skew angle under steady flow conditions. He 
obtained empirical equations to predict scour depth, scour hole radius and scour hole volume. [17] measured local scour hole contours around bridge piers under unsteady flow conditions. They used Ultrasonic Velocity Profiler (UVP) to measure temporal variation of scour depth by placing the device vertically. [21] investigated experimentally the flow field and the local scour around bridge pier of different shapes. They observed that the plan area of the scour hole in the case of the trapezoidal pier was larger compared to the triangular pier, but on the other hand the triangular pier created larger scour hole volume compared to the trapezoidal pier and a sharp nose with curved body was ideal for a bridge pier because of less scour around the pier.

The main objective of this study is to analyze the scour depth and the scour hole geometry due to various hydrographs in the case of five different pier shapes. The approach was based on the image processing with a video camera during unsteady flow conditions. The dimensions of the scour hole were determined by using the values of the scour contours obtained from the experiments. The experimental findings were evaluated by using the empirical expressions existing in the relevant literature. Although many studies have been conducted with circular piers, it is a matter of vital importance to study also prismatic shaped piers (rectangular with circular nose and rectangular with trapezoidal nose) since they are widely used in practice.

\section{EXPERIMENTAL SETUP AND MEASUREMENT PROCEDURE}

The experiments were carried out in the rectangular flume of $18.6 \mathrm{~m}$ length, $0.80 \mathrm{~m}$ width and $0.75 \mathrm{~m}$ depth with a bottom slope of 0.006, as shown in Fig. 1. The rectangular flume has transparent side walls made of plexiglass. Water was pumped from the main tank having a volume of $27 \mathrm{~m}^{3}$. The flume has a platform which is $1 \mathrm{~m}$ wide and $1.8 \mathrm{~m}$ height with ladder. The main tank and rectangular basin are at the downstream end of the flume. The water levels could be adjusted by means of a tail gate. The test section was $11 \mathrm{~m}$ from the flume entrance. Drive Link-C software was used to control pump speed which has a maximum capacity of $100 \mathrm{~L} / \mathrm{s}$. The hydrographs were generated by adjusting the pump speed. The uniform graded material with $\mathrm{D}_{50}=1.68 \mathrm{~mm}$ was used. The geometric standard deviation was $\sigma_{\mathrm{g}}=1.33 \mathrm{~mm}$. which implies that the sediment can be assumed as uniform and its specific gravity was 2.65 . The bed material and its grain distribution curve are shown in Fig. 2. Sieve analysis was performed with 4 different samples and grain distribution was obtained as given in Table 1 . The samples were taken from different locations of the flume. The geometric standard deviation was determined from $\sigma_{\mathrm{g}}=\sqrt{\frac{\mathrm{D}_{84.1}}{D_{15.9}}}=\sqrt{\frac{2.15}{1.22}}=1.33 \mathrm{~mm}$. Since this value is less than 1.4 the sediment can be assumed as uniform ([27] and [28]).

\subsection{Pier Types}

The experiments were performed with five different pier shapes; circular $(b=11 \mathrm{~cm})$, square $(b=8.5 \mathrm{~cm})$, rectangular $(\mathrm{b}=11.5 \mathrm{~cm})$, rectangular with circular nose (lenticular) $(\mathrm{b}=12$ $\mathrm{cm})$ and rectangular with trapezoidal nose $(\mathrm{b}=11 \mathrm{~cm})$. The piers were made of plexiglass and fixed into the sediment layer. The used pier shapes and dimensions are given in Fig. 3, together with the measurement points positions. The recording device 2 (camera) was used 
to record the time dependent scour depth values in front of the piers (point A). The recording device 1 recorded the temporal evolutions of the scour hole. The equilibrium scour depths at lateral side (point B) and at downstream end of the piers (point C) were determined by means of the laser meter and controlled by the records of the device 1 .
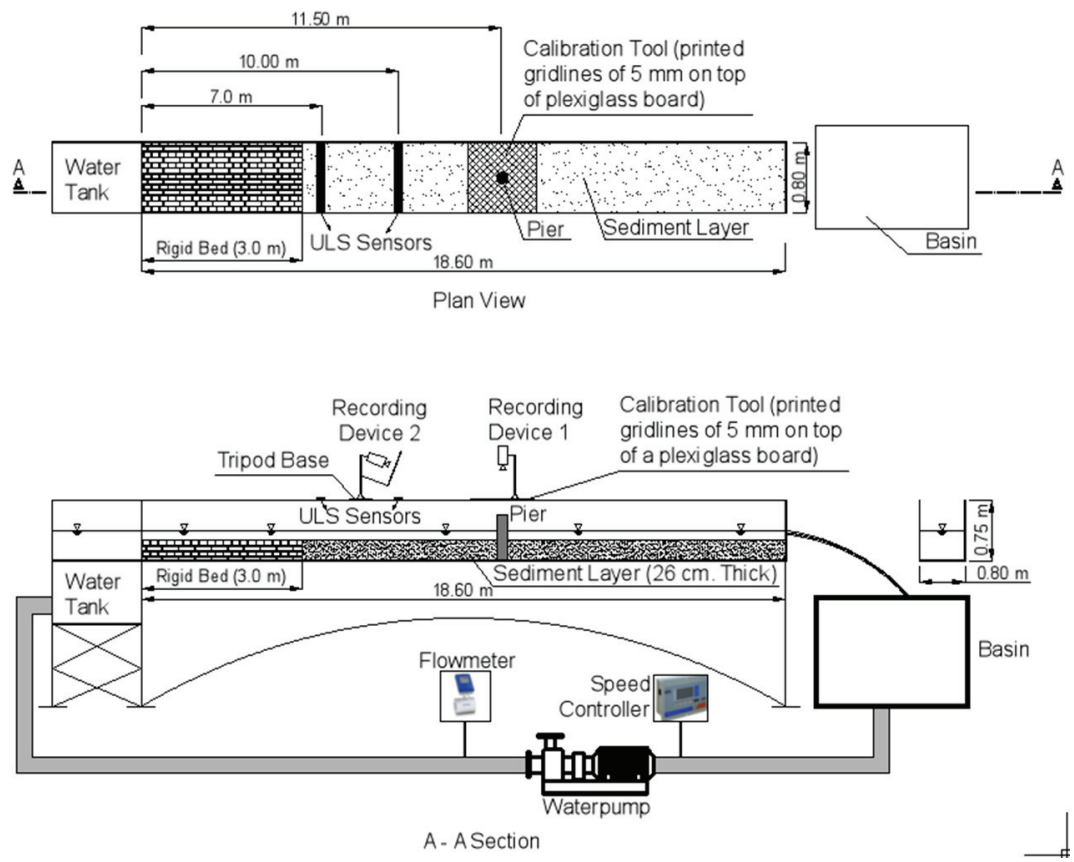

Figure 1 - The scheme of the experimental system [29]

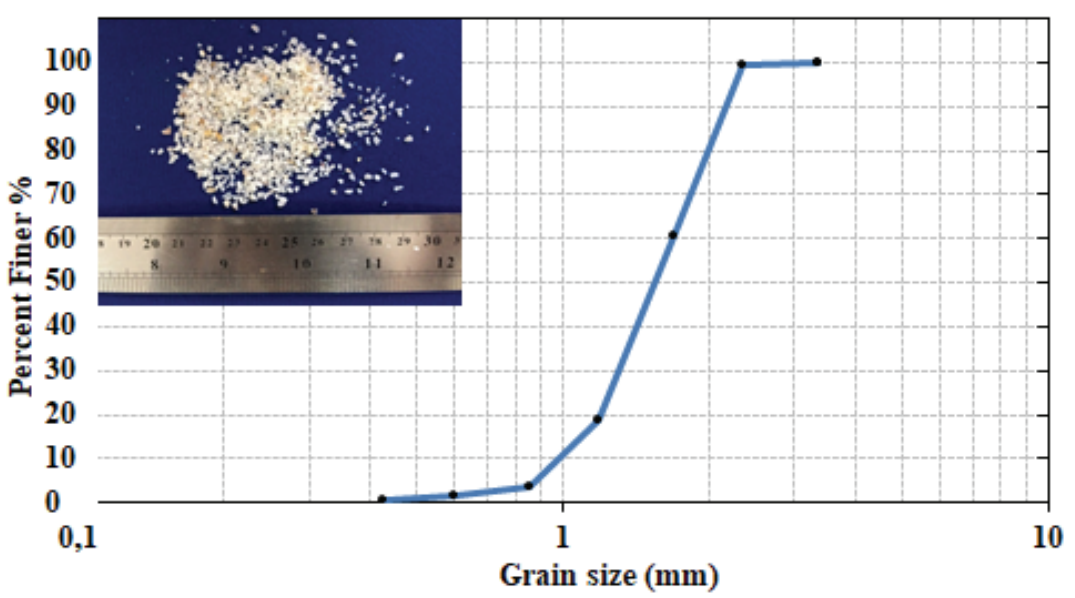

Figure 2 - Sediment sample used in this study [29] 
Table 1 - Summary of the sieve analysis

\begin{tabular}{|c|c|c|c|c|}
\hline Grain size (mm) & Sample 1 & Sample 2 & Sample 3 & Sample 4 \\
\hline $\mathbf{3 . 3 5}$ & 0.27 & 0.28 & 0.04 & 0.44 \\
\hline $\mathbf{2 . 3 6}$ & 2.16 & 2.62 & 1.39 & 1.97 \\
\hline $\mathbf{1 . 7}$ & 277.62 & 338.81 & 17.16 & 707.55 \\
\hline $\mathbf{1 . 1 7}$ & 293.67 & 381.62 & 201.5 & 627.43 \\
\hline $\mathbf{0 . 8 5}$ & 109.98 & 145.67 & 81.43 & 211.9 \\
\hline $\mathbf{0 . 6}$ & 14.05 & 27.77 & 10.37 & 37.93 \\
\hline $\mathbf{0 . 4 2 5}$ & 4.37 & 12.89 & 2.45 & 16.11 \\
\hline Sieve under & 5.92 & 9.02 & 4.81 & 9.92 \\
\hline $\boldsymbol{D}_{\boldsymbol{5 0}}$ & 1.69 & 1.66 & 1.67 & 1.71 \\
\hline $\boldsymbol{D}_{\boldsymbol{8 4 . 1}}$ & 2.15 & 2.14 & 2.17 & 2.18 \\
\hline $\boldsymbol{D}_{\mathbf{1 5 . 9}}$ & 1.22 & 1.21 & 1.22 & 1.24 \\
\hline
\end{tabular}

\subsection{Flow Conditions}

All experiments were performed in clear water conditions. Five types of hydrographs were generated by the adjustment of the pump rotational speed. During the first 5 minutes of the experiments the base flow, $\mathrm{Q}_{\mathrm{b}}(\mathrm{L} / \mathrm{s})$, was kept constant and then it was increased to the peak value, $\mathrm{Q}_{\mathrm{p}}(\mathrm{L} / \mathrm{s})$, under unsteady flow conditions. The generated triangular hydrographs are described in Table 2 and depicted in Fig. 4. The discharge values were recorded by the magnetic flow meter. The flow depths were measured by ULS, placed at $7^{\text {th }} \mathrm{m}$ and $10^{\text {th }} \mathrm{m}$ of the flume. The hydrographs ( Hid $_{\mathrm{ij}-\mathrm{k}}$ ) were described so that the subscripts $\mathrm{i}$ and $\mathrm{j}$ denote the rising and falling durations in minutes respectively, and the following subscript $\mathrm{k}$ indicates the peak discharge of the hydrograph in L/s.

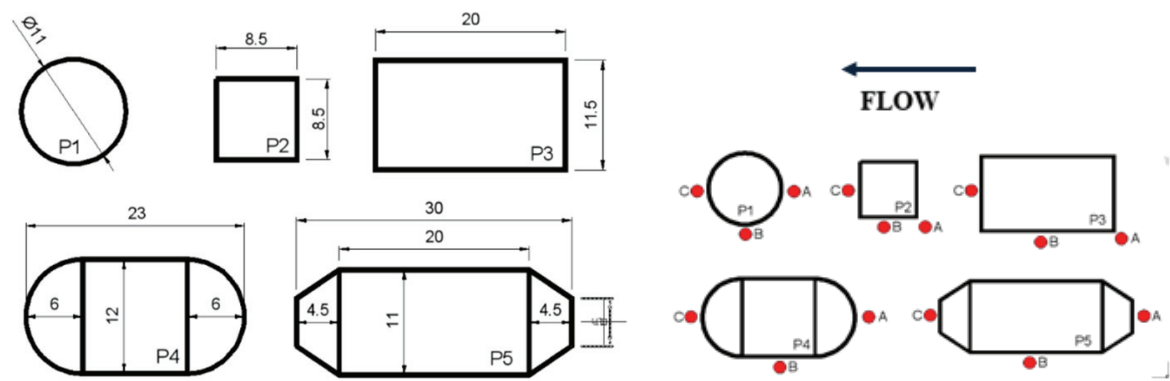

Figure 3 - Pier shapes used in experiments (all dimensions are in $\mathrm{cm}$ ) and measurement points $A, B$, and $C$ [29]

In all hydrographs the first part of 5 minutes duration corresponds to the steady flow. The values of the variables characterizing the experimental conditions are summarized in Table 
3. In this table, $\mathrm{h}=$ approach water depth, $\mathrm{u}=$ mean approach velocity, $\mathrm{u}_{\mathrm{c}}=$ mean approach critical velocity, $I=$ average flow intensity, $I=\frac{u}{u_{c}}$ and $F_{r}=$ Froude number.

Table 2 - Hydrograph characteristics with base flow rates, peak discharges and durations.

\begin{tabular}{|c|c|c|c|c|c|}
\hline \hline \multirow{2}{*}{$\begin{array}{c}\text { Hydrograph } \\
\text { Name }\end{array}$} & \multirow{2}{*}{$\begin{array}{c}\text { Hydrograph } \\
\text { Description }\end{array}$} & \multirow{2}{*}{$\begin{array}{c}\text { Base Flow } \\
\text { Rate } \\
\mathbf{Q}_{\mathbf{b}} \mathbf{( L / s )}\end{array}$} & $\begin{array}{c}\text { Peak Flow } \\
\text { Rate } \\
\mathbf{Q n n n y y}\end{array}$ & $\mathbf{Q}_{\mathbf{p}}(\mathbf{L} / \mathbf{s})$ & \multicolumn{2}{|c|}{ Duration (min) } \\
\cline { 5 - 6 } & Hid55-45 & 8 & 45 & 5 & Falling \\
\hline Hid1 & Hid55-63 & 8 & 63 & 5 & 5 \\
\hline Hid3 & Hid55-73 & 8 & 73 & 5 & 5 \\
\hline Hid4 & Hid1010-63 & 8 & 63 & 10 & 10 \\
\hline Hid5 & Hid2020-63 & 8 & 63 & 20 & 20 \\
\hline \hline
\end{tabular}

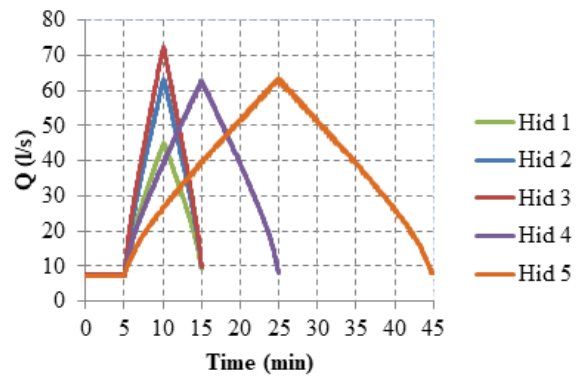

Figure 4 - Hydrographs used in the experiments [29]

Table 3 - Experimental conditions for each experiment

\begin{tabular}{|c|c|c|c|c|c|c|c|}
\hline \multirow{3}{*}{ 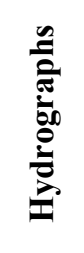 } & 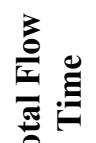 & $\begin{array}{c}\text { Discharge } \\
\mathbf{Q}_{\mathbf{b}}-\mathbf{Q}_{\mathbf{p}}\end{array}$ & $\begin{array}{l}\text { Approach } \\
\text { Water } \\
\text { Depth }\end{array}$ & $\begin{array}{c}\text { Mean } \\
\text { Velocity }\end{array}$ & $\begin{array}{c}\text { Mean } \\
\text { Critical } \\
\text { Velocity }\end{array}$ & $\begin{array}{c}\text { Flow } \\
\text { Intensity } \\
\text { Ratio } \\
\end{array}$ & \multirow[t]{2}{*}{$\begin{array}{c}\text { Froude } \\
\text { Number } \\
\text { Frb }_{\text {-Frp }}\end{array}$} \\
\hline & & & $\mathbf{h}_{\mathbf{b}}-\mathbf{h}_{\mathbf{p}}$ & $\mathbf{u}_{\mathbf{b}}-\mathbf{u}_{\mathbf{p}}$ & $\mathbf{u}_{\mathbf{c b}}-\mathbf{u}_{\mathbf{c p}}$ & $I_{p b}-I_{p p}$ & \\
\hline & $\min$ & $\mathbf{l} / \mathbf{s}$ & $\mathbf{c m}$ & $\mathbf{m} / \mathbf{s}$ & $\mathbf{m} / \mathbf{s}$ & & \\
\hline Hid1 & 15 & $8-45$ & $6-20.39$ & $0.21-0.28$ & $0.47-0.92$ & $0.45-0.30$ & $0.27-0.20$ \\
\hline Hid2 & 15 & $8-63$ & $6-22.61$ & $0.21-0.35$ & $0.47-0.93$ & $0.45-0.38$ & $0.27-0.23$ \\
\hline Hid3 & 15 & $8-73$ & $6-23.52$ & $0.21-0.39$ & $0.47-0.94$ & $0.45-0.41$ & $0.27-0.26$ \\
\hline Hid4 & 25 & $8-63$ & $6-22.61$ & $0.21-0.35$ & $0.47-0.93$ & $0.45-0.38$ & $0.27-0.23$ \\
\hline Hid5 & 45 & $8-63$ & $6-22.61$ & $0.21-0.35$ & $0.47-0.93$ & $0.45-0.38$ & $0.27-0.23$ \\
\hline
\end{tabular}

* the subscripts $\mathrm{b}$ and $\mathrm{p}$ denote base and peak values during hydrographs respectively. 
The average flow intensity varied in the range of $0.30<\mathrm{I}<0.45$ implying that the clear water scouring criterion was satisfied. The mean critical velocities $u_{c}$ were calculated using the logarithmic average velocity equation Eq. 1.

$$
\frac{u_{c}}{u_{* c}}=5.75 \log 5.53 \frac{h}{D_{50}}
$$

where; $\mathrm{D}_{50}$ being the median grain size. The critical shear velocity $\mathrm{u}_{*_{\mathrm{c}}}$ was found for $1 \mathrm{~mm} \leq \mathrm{D}_{50} \leq 100 \mathrm{~mm}$ by using the Eq. 2 [30], $\mathrm{D}_{50}$ being in $\mathrm{mm}$.

$u_{* C}=0.0305 \sqrt{D_{50}}-\frac{0.0065}{D_{50}}$

The Reynolds number varied between 18,300 and 38,300 implying that viscous effects could be overlooked [31].

\subsection{Experimental Procedure}

25 experiments were conducted with five different types of pier. The temporal variations of the scour depth at the upstream face of the pier, the maximum scour depths at the downstream and lateral faces of the pier were recorded simultaneously. The sediment bed was flattened before each experiment and water was supplied gently without causing any disturbance to the bed material. Before the tests, the bed levels were measured in order to specify the scour depths ds according to these premeasured values.

During the experiments, the cameras recorded the bed elevations allowing the determination of the scour depth at point A and the configuration of the scour hole. The length and width of the scour hole were also measured in the course of the experiments. Measurements were performed with two methods, namely by using a laser meter and by means of a video camera. Laser meter was used only at the end of the experiment, when the water was removed from the flume. Two video cameras were used; one located between $11^{\text {th }} \mathrm{m}$ and $12^{\text {th }} \mathrm{m}$ of the flume and the other located at $10^{\text {th }} \mathrm{m}$ of the flume with an angle of $45^{\circ}$ in order to obtain the plan view of the scour hole. The first camera was mounted $41.5 \mathrm{~cm}$ above $80 \mathrm{~cm} \times 100 \mathrm{~cm}$ plexiglass plate on which $5.0 \times 5.0 \mathrm{~mm}$ squares were drawn just like a squared paper. This plate was $54 \mathrm{~cm}$ far from the bed. The second camera was mounted $27 \mathrm{~cm}$ above $210 \times 297$ $\mathrm{cm}$ plexiglass plate with meshes of $5.0 \times 5.0 \mathrm{~mm}$. This plate was $120 \mathrm{~cm}$ far from the piers. The details of this configuration are given in Fig. 5.

At the end of the experiments, water was removed gently, and the bed topography was measured with laser meter and transmitted to Golden software Surfer program. The maximum scour depths were measured at points $\mathrm{B}$ and $\mathrm{C}$, by the laser meter.

The records were analyzed by the image processing technique to determine the time dependent scour depth and the scour hole area. A grid system $(1.0 \times 1.0 \mathrm{~cm}$ square $)$ was built around the pier and the scour hole contours were identified by surveying with laser meter. The results were plotted as contour lines of the scour hole with the Golden software Surfer program and converted to AutoCAD drawings. Many difficulties were encountered during the measurements. While water was rising during the hydrograph, the images of scour holes 
became overestimated due to the optical diffraction. At each time step, as water level above the layer of sediment was different, a calibration became necessary to determine the scoured area. To do so, a grid of one centimeter meshes was printed on a transparent plexiglass. The scour hole dimensions for corresponding times were plotted at AutoCAD.

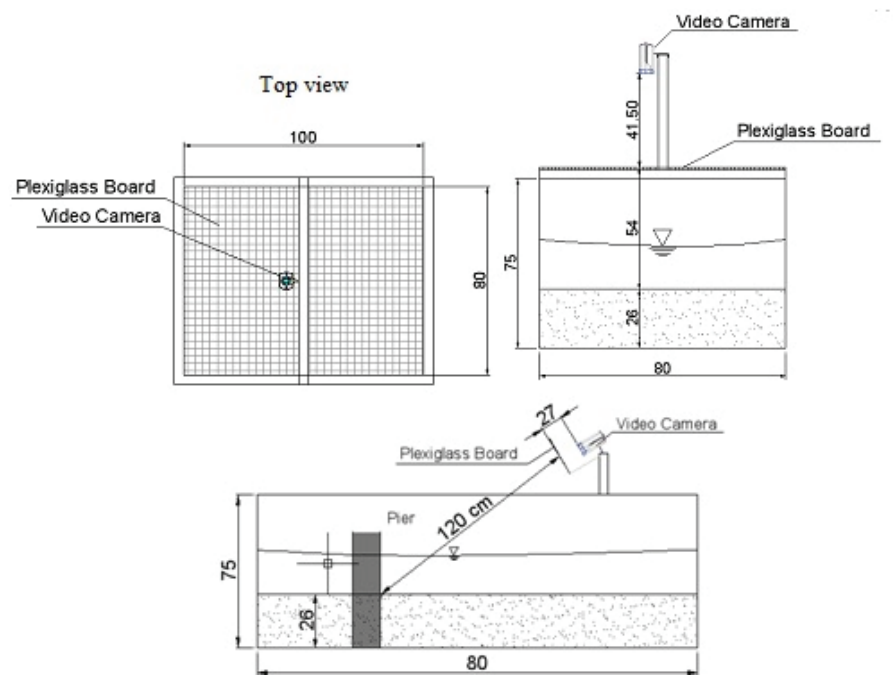

Figure 5 - Sketch to illustrate the measurement procedure by using two cameras [29]

\section{RESULTS AND DISCUSSIONS}

\subsection{Observations of Scour around the Piers of Different Shape}

At the end of each experiment, the dimensions of the scour hole were measured. The scouring photographs were taken after removing the water gently. Fig. 6 shows the photographs of the final scour geometries developed around the pier of five different shapes, namely circular $(\mathrm{P} 1)$, square $(\mathrm{P} 2)$, rectangular $(\mathrm{P} 3)$, rectangular with circular nose $(\mathrm{P} 4)$ and rectangular with trapezoidal nose (P5) at the end of experiments. It was observed that, the shapes of the pier significantly changed the scour holes geometry.

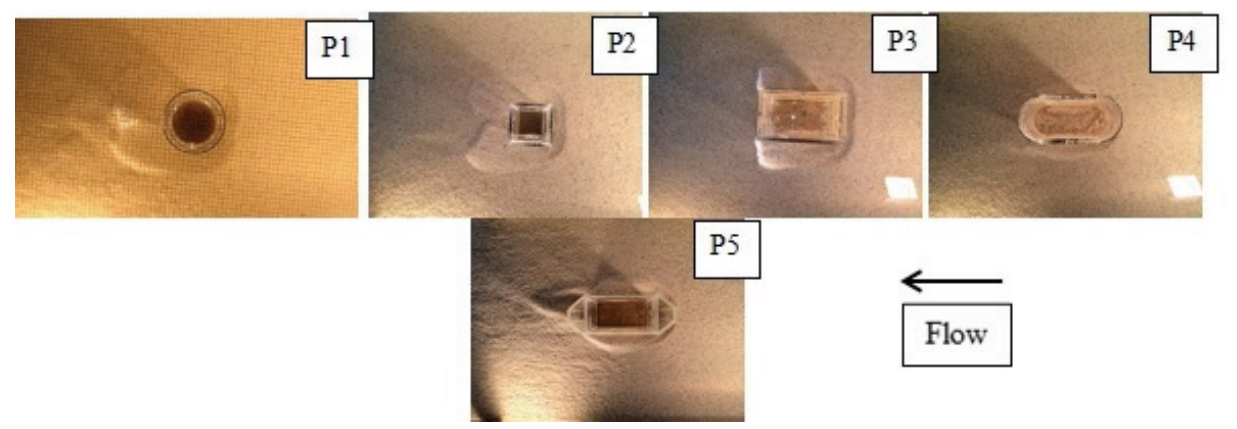

Figure 6 - Scour hole photographs at the end of the experiment P1 to P5 for Hid 1. [29] 
It was also observed that maximum scour depths occurred at the upstream face of the rounded piers and at the upstream corners for angular piers. The maximum scour depth values at measurements points A, B and C are summarized in Table 4, for different hydrographs. In Table 4, $\mathrm{d}_{\mathrm{sA}}(\mathrm{cm})$ denotes the maximum (equilibrium) scour depth at the upstream face of the pier, $d_{\mathrm{sB}}(\mathrm{cm})$ and $\mathrm{d}_{\mathrm{sC}}(\mathrm{cm})$ are the maximum scour depths at the lateral and the downstream faces of the pier, respectively. The final surrounding bed configurations, determined at the end of each experiment, are presented in Fig. 7 to 11. The distances are in $\mathrm{cm}$. The contour plots are generated by the measurements of the elevations using point gauge by Surfer program in order to indicate the scouring and deposition zones at the upstream and downstream regions of the pier. As stated in [5], [6] and [32], three scouring forms were observed around the piers. At the upstream of the piers (Point A) the frontal scour due to the horseshoe vortices was observed. At the lateral sides of the piers (Point B) the observed scouring was due to the flow separation and shear layers and the succeeding turbulent wakes induced the deformation of the bed at the downstream of the piers (Point C). The frontal scour was mostly developed in the cases of the square pier P2 and the rectangular pier P3, compared to the rounded piers such as the circular P1 and the rectangular with circular nose pier P4 and the rectangular with trapezoidal nose P5 piers. The equilibrium scour depth at lateral side (point B) was not significant for the $r$

ectangular with trapezoidal nose pier P5. The deposition was significant at point B for the circular pier P1 and the square pier P2.

Table 4 - Maximum scour/deposition depths measured at the end of hydrographs

\begin{tabular}{|c|c|c|c|c|c|c|}
\hline \multirow{2}{*}{\multicolumn{2}{|c|}{ Scour Depths (cm) }} & \multicolumn{5}{|c|}{ Hydrographs } \\
\hline & & \multirow{2}{*}{$\begin{array}{l}\text { Hid55-45 } \\
\text { (HID 1) } \\
3.8\end{array}$} & \multirow{2}{*}{$\begin{array}{l}\text { Hid55-63 } \\
\text { (HID 2) } \\
6\end{array}$} & \multirow{2}{*}{$\begin{array}{l}\text { Hid55-73 } \\
\text { (HID 3) } \\
6\end{array}$} & \multirow{2}{*}{$\begin{array}{l}\text { Hid1010-63 } \\
\text { (HID 4) } \\
6\end{array}$} & \multirow{2}{*}{$\begin{array}{l}\text { Hid2020-63 } \\
\text { (HID 5) } \\
6.5\end{array}$} \\
\hline \multirow{3}{*}{$\bar{a}$} & $\mathrm{~d}_{\mathrm{sA}}$ & & & & & \\
\hline & $\mathrm{d}_{\mathrm{sB}}$ & 3.4 & 5 & 4.5 & 3.6 & 5.5 \\
\hline & $\mathrm{d}_{\mathrm{SC}}$ & $0.8 \mathrm{~d}$ & $0.6 \mathrm{~d}$ & 0.5 & 0 & 1.7 \\
\hline \multirow{3}{*}{ 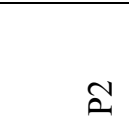 } & $\mathrm{d}_{\mathrm{sA}}$ & 4 & 6.5 & 7.5 & 6.5 & 7.5 \\
\hline & $\mathrm{d}_{\mathrm{sB}}$ & 2.9 & 4.5 & 7 & 6.5 & 7.5 \\
\hline & $\mathrm{d}_{\mathrm{sC}}$ & $0.8 \mathrm{~d}$ & 0.5 & 1.5 & 0.5 & 1.5 \\
\hline \multirow{3}{*}{$\tilde{\kappa}$} & $\mathrm{d}_{\mathrm{sA}}$ & 4.5 & 7.5 & 8.5 & 8 & 8 \\
\hline & $\mathrm{d}_{\mathrm{sB}}$ & 0.5 & 0.8 & 2 & 0 & 1.5 \\
\hline & $\mathrm{d}_{\mathrm{sC}}$ & $0.2 \mathrm{~d}$ & $1 \mathrm{~d}$ & $0.7 \mathrm{~d}$ & $1 d$ & $0.5 \mathrm{~d}$ \\
\hline \multirow{3}{*}{$\Xi$} & $\mathrm{d}_{\mathrm{sA}}$ & 4.2 & 4.4 & 6 & 4.4 & 5.5 \\
\hline & $d_{\mathrm{sB}}$ & 0.5 & 0.6 & 1.5 & 0.4 & 2.5 \\
\hline & $\mathrm{d}_{\mathrm{sC}}$ & $0.1 \mathrm{~d}$ & $0.1 \mathrm{~d}$ & 0 & $0.1 \mathrm{~d}$ & $0.8 \mathrm{~d}$ \\
\hline \multirow{3}{*}{$\curvearrowleft$} & $\mathrm{d}_{\mathrm{sA}}$ & 2.2 & 4 & 5 & 4.5 & 5.5 \\
\hline & $d_{\mathrm{sB}}$ & 0 & 0 & 0 & 0 & 1 \\
\hline & $\mathrm{d}_{\mathrm{SC}}$ & $1.3 \mathrm{~d}$ & $1.4 \mathrm{~d}$ & $1.6 \mathrm{~d}$ & $2.2 \mathrm{~d}$ & $1.2 \mathrm{~d}$ \\
\hline
\end{tabular}

Note: "d" means deposition in $\mathrm{d}_{\mathrm{sC}}$ point. 

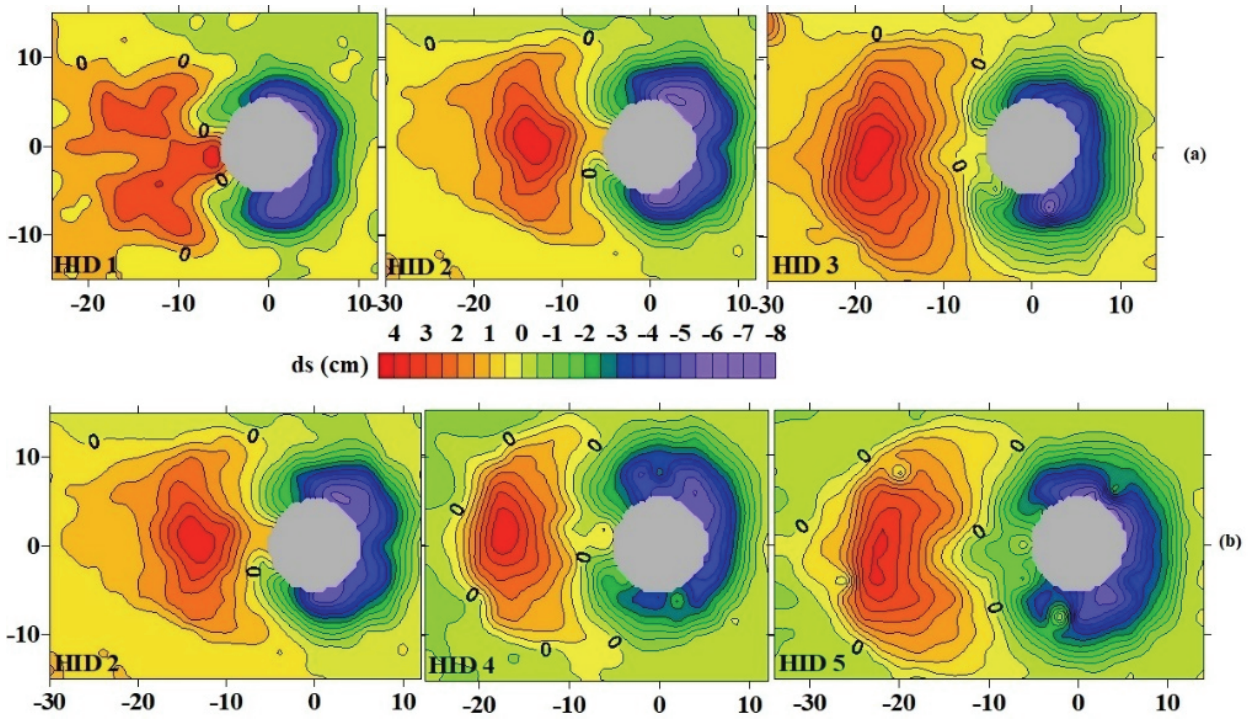

Figure 7 - Bed configurations in the case of the circular pier P1 for the hydrographs a) having the same duration and different flow rate peaks b) having the same flow rate and different durations.
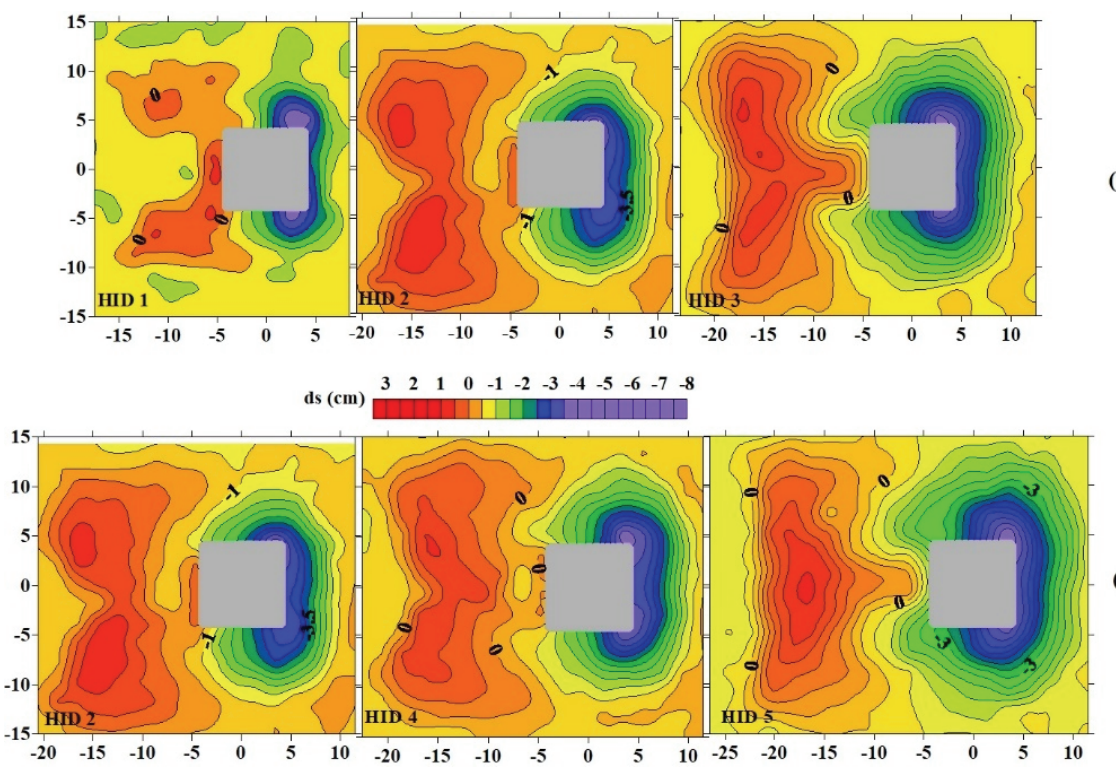

(b)

Figure 8 - Bed configurations in the case of the square pier P2 for the hydrographs a) having the same duration and different flow rate peaks b) having the same flow rate and different durations. 

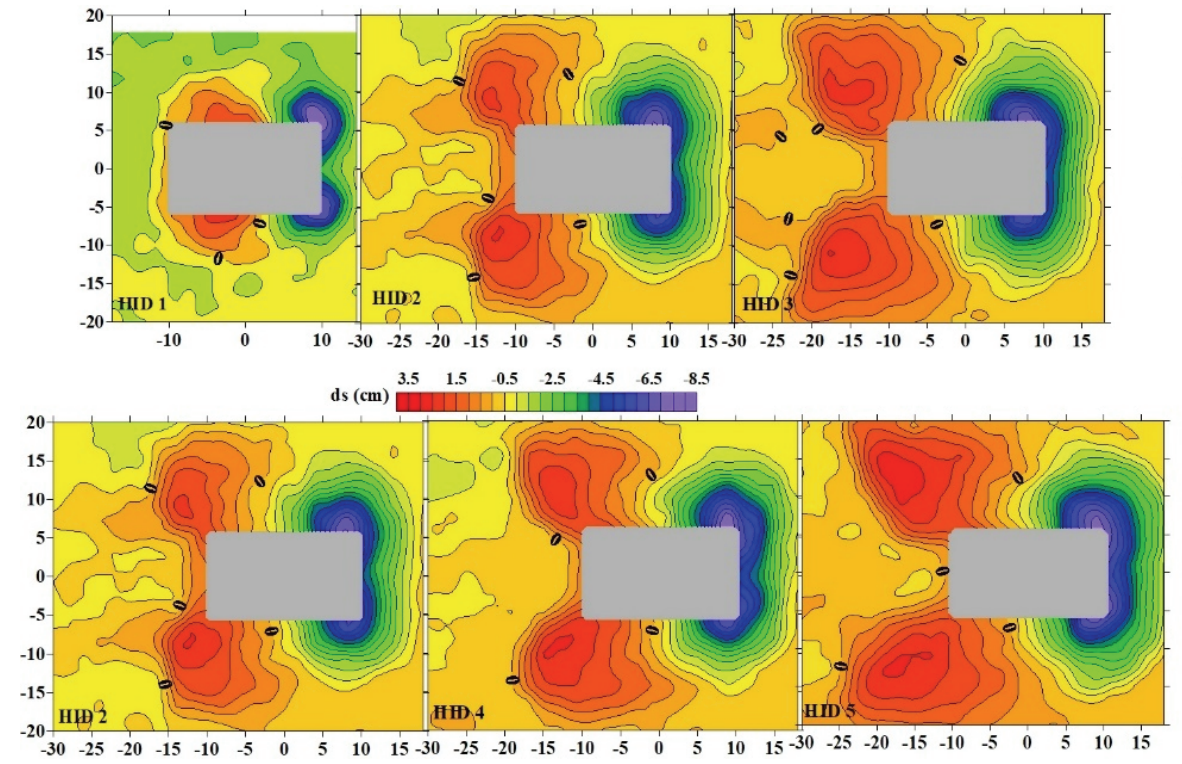

(b)

Figure 9 - Bed configurations in the case of the rectangular pier P3 for the hydrographs a) having the same duration and different flow rate peaks b) having the same flow rate and different durations.
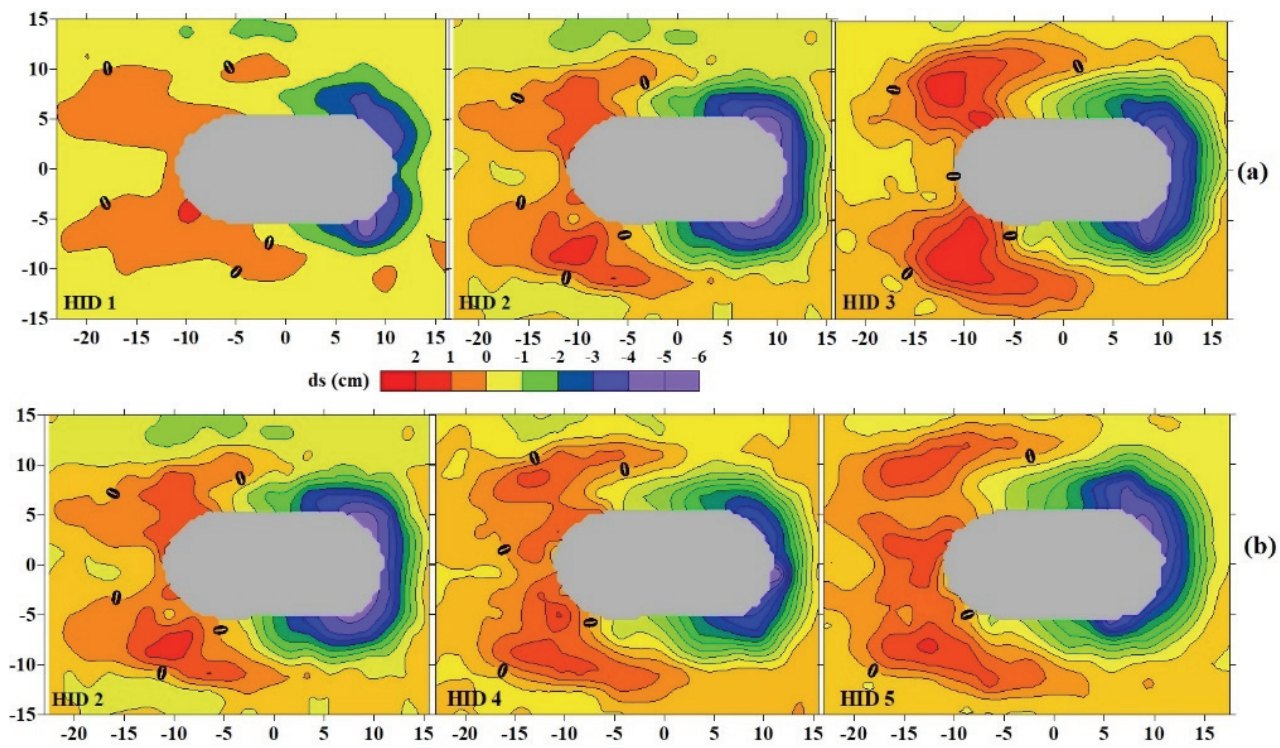

(b)

Figure 10 - Bed configurations in the case of the rectangular with the circular nose pier P4 for the hydrographs a) having the same duration and different flow rate peaks b) having the same flow rate and different durations. 

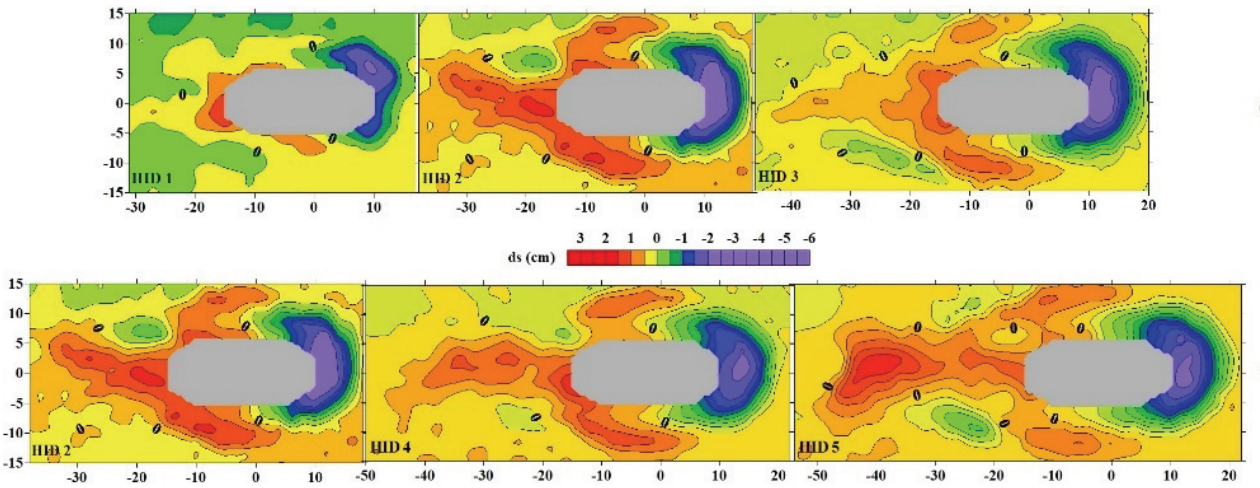

Figure 11 - Bed configurations in the case of the rectangular with the trapezoidal nose pier P5 for the hydrographs a) having the same duration and different flow rate peaks b) having the same flow rate and different durations.

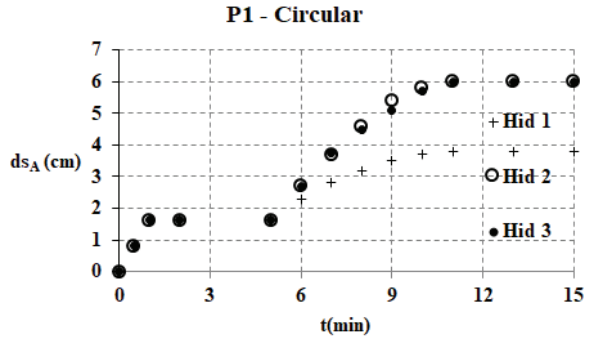

(a)

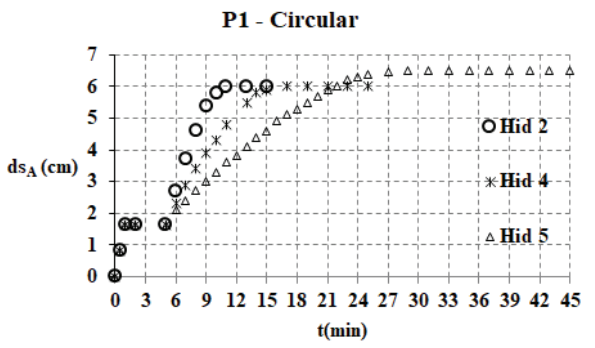

(b)

Figure 12 - Temporal variations of the scour depth at point A for the circular pier P1 for hydrographs a) with different peak flow rate b) with different duration

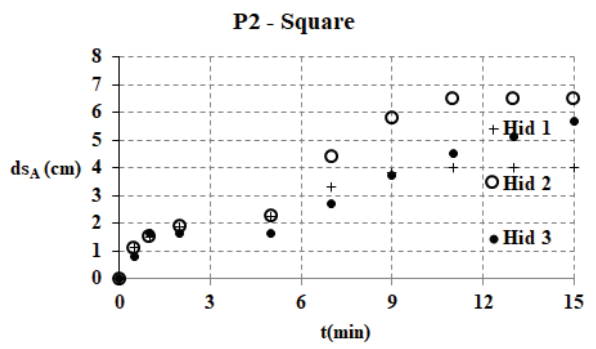

(a)

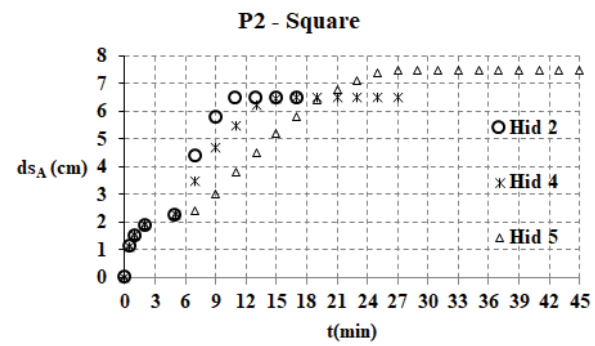

(b)

Figure 13 - Temporal variations of the scour depth at point A for the square pier P2 for hydrographs a) with different peak flow rate b) with different duration 
The time dependent scour depths at point A for all experiments are given in Fig. 12 to Fig. 16. For each of the piers, the scour depth initially increased and reached a maximum at about peak flow rate. As expected, larger maximum scour depths were developed in the case of the piers $\mathrm{P} 2$ and $\mathrm{P} 3$, compared to the piers $\mathrm{P} 1, \mathrm{P} 4$ and $\mathrm{P} 5$. It was revealed that the peak flow rate values of the hydrographs effected the maximum scour depths much more than the durations of the hydrograph limbs.

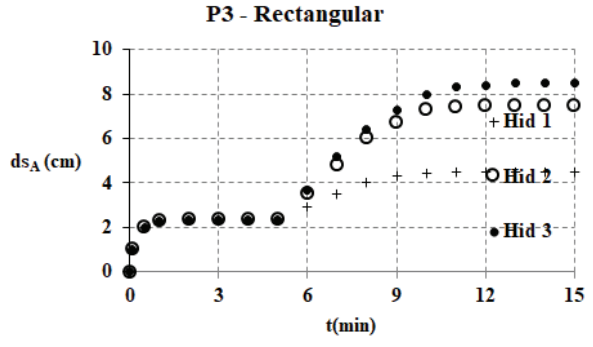

(a)

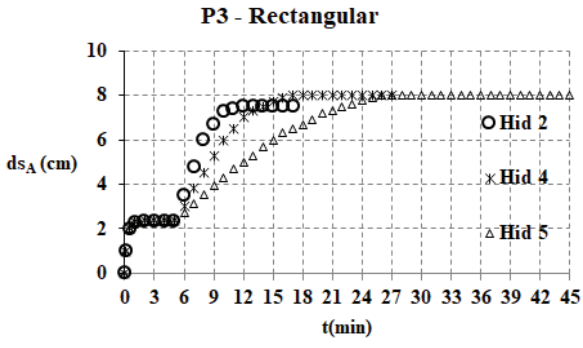

(b)

Figure 14 - Temporal variations of the scour depth at point A for the rectangular pier P3 for hydrographs a) with different peak flow rate b) with different duration

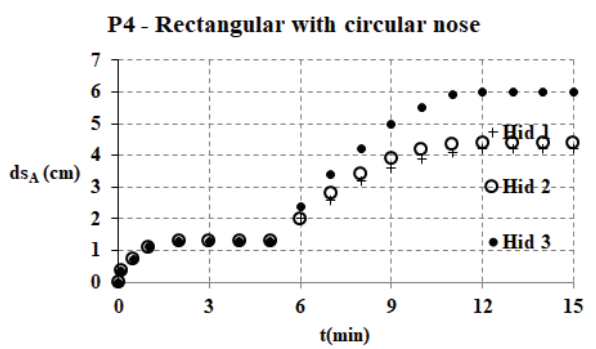

(a)

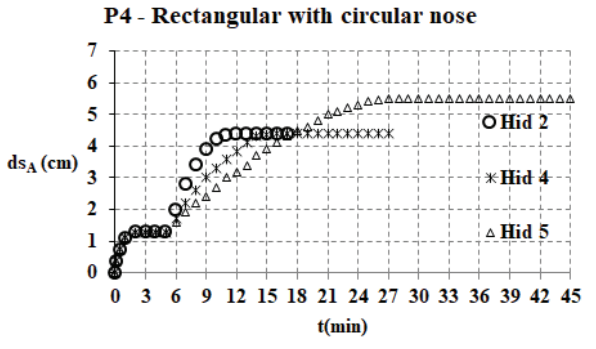

(b)

Figure 15 - Temporal variations of the scour depth at point A for circular nose pier P4 for hydrographs a) with different peak flow rate b) with different duration

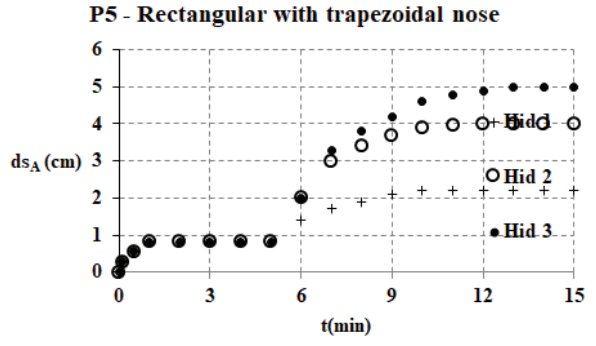

(a)

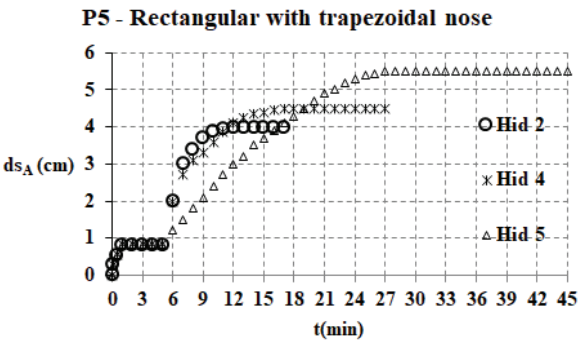

(b)

Figure 16 - Temporal variations of the scour depth at point A for the trapezoidal nose pier

$P 5$ for hydrographs a) with different peak flow rate b) with different duration 
The fractional changes in the scour depth at point $A$ with respect to the fractional changes in the peak flow rate were investigated by taking the smallest value $\left(Q_{p}=451 / s\right)$ as reference value. The so obtained percentages are given in Table $5 \mathrm{a}$.

For circular pier P1, when the flow rate was increased to $63 \mathrm{l} / \mathrm{s}$ (by 40\%) and $73 \mathrm{l} / \mathrm{s}$ (by $62 \%$ ), these increases caused the same change of $60 \%$ in the scour depth. In the case of square pier $\mathrm{P} 2$, when the flow rate was increased to $63 \mathrm{l} / \mathrm{s}$ and $73 \mathrm{l} / \mathrm{s}$, these increases caused the changes of $62 \%$ and $88 \%$ in the scour depth, respectively. These changes were observed as $40 \%$ and $62 \%$ in the case of rectangular pier P3, 5\% and $42 \%$ for rectangular pier with circular nose $\mathrm{P} 4$ and $82 \%$ and $130 \%$ for rectangular pier with triangular nose P5, respectively.

Table 5 a - Fractional changes in the scour depth in terms of fractional changes in the flow rate

\begin{tabular}{|l|l|l|l|l|l|l|l|l|l|l|}
\hline Pier type & \multicolumn{3}{l|l|}{ P1 } & \multicolumn{1}{l|l}{ P2 } & \multicolumn{1}{l|}{ P3 } & \multicolumn{2}{l|}{ P4 } & \multicolumn{2}{l|}{ P5 } \\
\hline$\Delta \mathbf{Q}_{\mathbf{p}} / \mathbf{Q}_{\text {pref }}(\mathbf{\%})$ & 40 & 62 & 40 & 62 & 40 & 62 & 40 & 62 & 40 & 62 \\
\hline $\mathbf{d}_{\mathbf{s}} / \mathbf{d}_{\mathbf{s o}}(\mathbf{\%})$ & 60 & 60 & 62 & 88 & 67 & 88 & 5 & 42 & 82 & 130 \\
\hline
\end{tabular}

The fractional changes in the scour depth at point A with respect to the fractional changes in the hydrograph rising limb duration were investigated by taking the smallest value $\left(t_{p}=5\right.$ $\min$ ) as reference value. The so obtained percentages are given in Table $5 \mathrm{~b}$.

For circular pier P1, when the hydrograph rising limb duration was increased to $10 \mathrm{~min}$ (by $100 \%$ ) and $15 \mathrm{~min}$ (by 200\%), these increases caused $0 \%$ and $9 \%$ increase in the scour depth, respectively. In the case of square pier $\mathrm{P} 2$, when the hydrograph rising limb duration was increased to $10 \mathrm{~min}$ and $15 \mathrm{~min}$, these increases caused $0 \%$ and $15 \%$ increase in the scour depth, respectively. These changes were observed as $8 \%$ and $8 \%$ in the case of rectangular pier $\mathrm{P} 3,0 \%$ and $25 \%$ for rectangular pier with circular nose $\mathrm{P} 4$, and $13 \%$ and $38 \%$ for rectangular pier with triangular nose $\mathrm{P} 5$, respectively.

Table $5 b$ - Fractional changes in the scour depth in terms of fractional changes in the rising limb duration

\begin{tabular}{|l|l|l|l|l|l|l|l|l|l|l|}
\hline Pier type & \multicolumn{3}{l}{ P1 } & \multicolumn{2}{l|}{ P2 } & \multicolumn{2}{l|}{ P3 } & \multicolumn{2}{l|}{ P4 } & \multicolumn{2}{l|}{ P5 } \\
\hline$\Delta \mathbf{t} / \mathbf{t}_{\text {ref }}(\mathbf{( \% )}$ & 100 & 200 & 100 & 200 & 100 & 200 & 100 & 200 & 100 & 200 \\
\hline $\mathbf{d}_{\mathbf{s}} / \mathbf{d}_{\mathbf{s o}}(\mathbf{( \% )}$ & 0 & 9 & 0 & 15 & 8 & 8 & 0 & 25 & 13 & 38 \\
\hline
\end{tabular}

The maximum scour depths were first observed at the lateral sides of the pier and then they migrated to the upstream of the pier. Higher flow velocities caused greater scour depths, as expected. For all the hydrographs, the maximum scour depth occurred after the peak flow rate was reached. [14], [12], [27] and [19] studied the temporal scour depth variations under unsteady flow conditions and showed that the recession period of hydrograph played a minor role in the scouring process. As seen in Table 5 and Fig. 12 to 16 this fact was also observed 
in our experiments. In Table $6, \mathrm{t}_{\mathrm{p}}$ and $\mathrm{t}_{\mathrm{se}}$ denote times to reach the peak discharge and equilibrium scour depth, respectively.

Table 6 - Times to reach the peak discharge and equilibrium scour depth

\begin{tabular}{|c|c|c|c|c|c|c|c|c|c|c|c|c|c|c|c|}
\hline \multirow{2}{*}{$\begin{array}{l}\text { Pier } \\
\text { ID. }\end{array}$} & \multicolumn{3}{|c|}{ Hid55-45 } & \multicolumn{3}{|c|}{ Hid55-63 } & \multicolumn{3}{|c|}{ Hid55-73 } & \multicolumn{3}{|c|}{ Hid1010-63 } & \multicolumn{3}{|c|}{ Hid2020-63 } \\
\hline & tp & tse & $\%$ & tp & tse & $\%$ & tp & tse & $\%$ & tp & tse & $\%$ & tp & tse & $\%$ \\
\hline P1 & 10 & 10.5 & 97 & 10 & 10.5 & 95 & 10 & 10.6 & 98 & 15 & 16 & 93 & 25 & 26.4 & 91 \\
\hline $\mathbf{P 2}$ & 10 & 10.5 & 95 & 10 & 10.6 & 98 & 10 & 10.6 & 99 & 15 & 16 & 98 & 25 & 26.5 & 98 \\
\hline P3 & 10 & 10.5 & 97 & 10 & 10.6 & 93 & 10 & 10.6 & 98 & 15 & 16.5 & 97 & 25 & 26.5 & 98 \\
\hline P4 & 10 & 10.5 & 98 & 10 & 10.5 & 98 & 10 & 10.5 & 99 & 15 & 16 & 98 & 25 & 26.4 & 98 \\
\hline P5 & 10 & 10.5 & 98 & 10 & 10.5 & 99 & 10 & 10.5 & 99 & 15 & 16 & 95 & 25 & 26.4 & 96 \\
\hline
\end{tabular}

Note: \% means percentage of the maximum scour depth at the peak time. $t_{p}$ and $t_{\mathrm{se}}$ are in minute.

\subsection{Comparison of the Measured Time Dependent Scour Depths ds(t) for Circular Pier P1 with the Equations Proposed by [27] and [33]}

[27] and [33] proposed the empirical relations based on their experiments performed under unsteady flow conditions with triangular hydrographs. They used the reference length $L_{R}$ that involves the pier width $b$ (for circular piers $b=D$ ) and the approach flow depth $h$. The dimensionless time dependent scour depth $d_{s}(t) / L_{R}$ is expressed as:

$\frac{d_{S}(t)}{L_{R}}=0.068 K_{s} \sigma_{g}{ }^{-0.5} F_{d}{ }^{1.5} \log (T)$

where $L_{R}=(h A)^{1 / 3}, \mathrm{~A}=$ the cross sectional area of the pier, $\mathrm{Ks}=$ pier shape coefficient, $\sigma_{\mathrm{g}}$ $=$ geometric standard deviation of particle size distribution, $\mathrm{F}_{\mathrm{d}}=$ densimetric particle Froude number, $F_{d}=\frac{u}{\sqrt{g^{\prime} D_{50}}}, \mathrm{~g}^{\prime}=$ reduced gravitational acceleration, $g^{\prime}=\left(\left(\rho_{s}-\rho\right) / \rho\right) g \mathrm{~T}$ is a dimensionless time parameter $T=\frac{t}{t_{R}}, \mathrm{t}$ and $t_{\mathrm{R}}$ being time and time scale with $t_{R}=$ $\frac{\sigma_{g^{\frac{1}{3}}} \sqrt{g^{\prime} D_{50}}}{L_{R}} t$. [33] developed the formula previously proposed by [27] and generalized temporal scour depth due to a single peaked flood wave. They combined [12] and [27] formula with Manning equation. [27] rewrote the formula as:

$\frac{d_{s}\left(\gamma T_{M}\right)}{L_{R}}=0.068 K_{s} \sigma_{g}{ }^{-0.5} F_{d}{ }^{1.5} \log \left(\gamma T_{M}\right)$

where; the subscript $M$ denotes the peak flow, $T_{M}=t / t_{M}$ is the normalized time and $\gamma=$ $t_{M} / t_{R}$ such that $T=\gamma T_{M}$, with $t_{M}=$ time to peak of the flood hydrograph. [33] used the following expression shown in Eq. 5. 
$Q_{M}=\left[T_{M} \exp \left(1-T_{M}\right)\right]^{n}$

where $n=$ the hydrograph shape parameter, $n>1$. In this study the shape factor was determined by using their procedure and the value of $\mathrm{n}$ was obtained as 5 . The optimum computation step length $\Delta \mathrm{T}_{\mathrm{M}}$ value was taken as $\Delta \mathrm{T}_{\mathrm{M}}=0.01$, as suggested. Fig. 17 represents the measured temporal scour depths and those calculated from [27] and [33] together with the band of $\pm 25 \%$. As seen from this figure, the experimental values were found not to be in agreement with those obtained from equation of [27]. The numerical results obtained from equation of [27] found to be underestimated in all cases. It was revealed that the compatibility between the values observed in the experiments and those obtained from [33] was better.

(a)

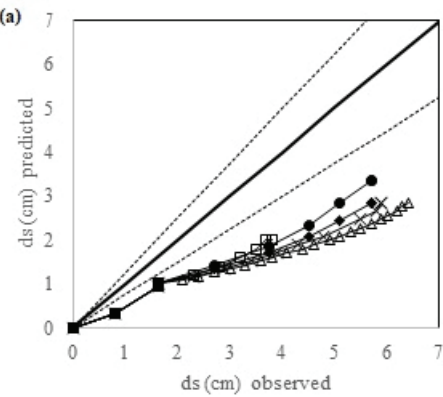

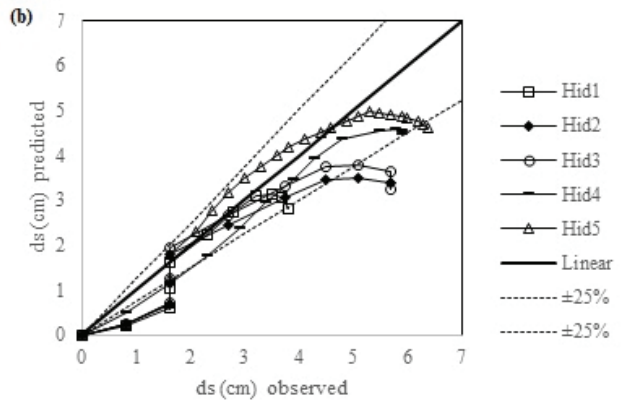

Figure 17 - Measured temporal variations of the scour depths and those calculated by using the equations proposed by a) [27] and b) [33]

\subsection{Derivation of the Empirical Equation}

The experimental findings were used to derive the empirical relations for the dimensionless scour depth ds (t) / $L_{R}$ as proposed by [27] and [33] by performing nonlinear regression analysis. Depending upon the dimensionless parameters taken into consideration 3 different scenarios were studied (Table 7). The constant factor considered in the relations corresponds to the shape factor $\mathrm{K}_{\mathrm{s}}$ which is assumed to be equal to 1 in the case of circular pier. The following scenarios are used considering the dimensionless variables indicated below:

Table 7 - Scenarios for nonlinear regression analysis

Scenario 1: $\frac{d_{s}(t)}{L_{R}}=f_{1}\left(F_{d}, I, \frac{h}{b}, \frac{b}{D_{50}}, T\right)$

Scenario 2: $\frac{d_{s}(t)}{L_{R}}=f_{2}\left(F_{d}, I, \frac{b}{D_{50}}, T\right)$

Scenario 3: $\frac{d_{s}(t)}{L_{R}}=f_{3}\left(F_{d}, I, T\right)$

The considered dimensionless parameters and so obtained empirical relations, together with the coefficients of determination are given in Tables 8 to 12 . The largest coefficients of determination $\mathrm{R}^{2}$ were obtained in the case of the Scenario 1 . 
Table 8 - Regression Equations for 3 different scenarios for P1

\begin{tabular}{|c|l|c|}
\hline Scenarios & \multicolumn{1}{|c|}{ Regression Equation } & $R^{2}$ \\
\hline$f 1$ & $\frac{d_{s}(t)}{L_{R}}=F_{d}{ }^{2.256} I^{-2.226} \frac{h^{0.026}}{b}{\frac{b}{D_{50}}}^{-1.085} \log (T)$ & 0.93 \\
\hline \multirow{2}{*}{$f 2$} & $\frac{d_{s}(t)}{L_{R}}=F_{d}{ }^{2.410} I^{-2.382}{\frac{b}{D_{50}}}^{-1.130} \log (T)$ & 0.91 \\
\hline$f 3$ & $\frac{d_{s}(t)}{L_{R}}=F_{d}{ }^{-0.968} I^{1.1914} \log (T)$ & 0.76 \\
\hline
\end{tabular}

Table 9 - Regression Equations for 3 different scenarios for P2

\begin{tabular}{|c|c|c|}
\hline Scenarios & Regression Equation & $R^{2}$ \\
\hline$f 1$ & $\frac{d_{s}(t)}{L_{R}}=0.993 F_{d}{ }^{2.256} I^{-2.226} \frac{h^{0.026}}{b}{\frac{b}{D_{50}}}^{-1.085} \log (T)$ & 0.91 \\
\hline$f 2$ & $\frac{d_{s}(t)}{L_{R}}=0.993 F_{d}^{2.410} I^{-2.382}{\frac{b}{D_{50}}}^{-1.130} \log (T)$ & 0.81 \\
\hline$f 3$ & $\frac{d_{s}(t)}{L_{R}}=0.890 F_{d}^{-0.968} I^{1.1914} \log (T)$ & 0.48 \\
\hline
\end{tabular}

Table 10 - Regression Equations for 3 different scenarios for P3

\begin{tabular}{|c|c|c|}
\hline Scenarios & Regression Equation & $R^{2}$ \\
\hline$f 1$ & $\frac{d_{s}(t)}{L_{R}}=1.346 F_{d}^{2.256} I^{-2.226} \frac{h}{b}^{0.026}{\frac{b}{D_{50}}}^{-1.085} \log (T)$ & 0.91 \\
\hline$f^{2}$ & $\frac{d_{s}(t)}{L_{R}}=1.352 F_{d} 2.410 I^{-2.382}{\frac{b}{D_{50}}}^{-1.130} \log (T)$ & 0.81 \\
\hline$f 3$ & $\frac{d_{s}(t)}{L_{R}}=0.808 F_{d}{ }^{-0.968} I^{1.1914} \log (T)$ & 0.51 \\
\hline
\end{tabular}

Table 11 - Regression Equations for 3 different scenarios for P4

\begin{tabular}{|c|c|c|}
\hline Scenarios & Regression Equation & $R^{2}$ \\
\hline$f 1$ & $\frac{d_{s}(t)}{L_{R}}=0.869 F_{d}{ }^{2.256} I^{-2.226} \frac{h}{b}^{0.026}{\frac{b}{D_{50}}}^{-1.085} \log (T)$ & 0.95 \\
\hline$f^{2}$ & $\frac{d_{s}(t)}{L_{R}}=0.873 F_{d}^{2.410} I^{-2.382}{\frac{b}{D_{50}}}^{-1.130} \log (T)$ & 0.85 \\
\hline$f 3$ & $\frac{d_{s}(t)}{L_{R}}=0.491 F_{d}^{-0.968} I^{1.1914} \log (T)$ & 0.58 \\
\hline
\end{tabular}


Table 12 - Regression Equations for 3 different scenarios for P5

\begin{tabular}{|c|c|c|}
\hline Scenarios & Regression Equation & $R^{2}$ \\
\hline$f 1$ & $\frac{d_{s}(t)}{L_{R}}=0.757 F_{d}{ }^{2.256} I^{-2.226} \frac{h}{b}^{0.026}{\frac{b}{D_{50}}}^{-1.085} \log (T)$ & 0.94 \\
\hline$f^{2}$ & $\frac{d_{s}(t)}{L_{R}}=0.759 F_{d}^{2.410} I^{-2.382}{\frac{b}{D_{50}}}^{-1.130} \log (T)$ & 0.84 \\
\hline$f 3$ & $\frac{d_{s}(t)}{L_{R}}=0.465 F_{d}^{-0.968} I^{1.1914} \log (T)$ & 0.48 \\
\hline
\end{tabular}

Since experimental studies performed in unsteady flow conditions are relatively rare, our suggested relations were tested with limited data available in the literature. Experimental findings obtained by [27] and [34] were tested and obtained results are illustrated in Fig. 18a and 18b. An acceptable agreement was found in the case of scenario 1 for circular piers. The geometric and hydraulic parameters corresponding to these experiments are summarized in Table 13.

Table 13 - Geometric and Hydraulic Parameters of Previous Studies

\begin{tabular}{|c|c|c|c|c|c|}
\hline Experiment No & $\begin{array}{c}\mathrm{D} \\
(\mathrm{cm})\end{array}$ & $\begin{array}{c}\mathrm{hM} \\
(\mathrm{cm})\end{array}$ & $\begin{array}{c}\mathrm{d} 50 \\
(\mathrm{~mm})\end{array}$ & $\sigma \mathrm{g}$ & $\mathrm{FdM}$ \\
\hline OH_HYD 1 & 11 & 15 & 3.1 & 2.15 & 1.960 \\
\hline OH_HYD 2 & 11 & 17 & 3.1 & 2.15 & 2.260 \\
\hline OH_HYD 3 & 11 & 19 & 3.1 & 2.15 & 2.580 \\
\hline OH_HYD 4 & 11 & 17 & 3.1 & 2.15 & 2.280 \\
\hline Arkis - HYD 1 & 4 & 22.6 & 1.68 & 1.3 & 1.197 \\
\hline Arkis - HYD 1 & 8 & 22.6 & 1.68 & 1.3 & 1.197 \\
\hline Arkis - HYD 1 & 15 & 22.6 & 1.68 & 1.3 & 1.197 \\
\hline Arkis - HYD 1 & 20 & 22.6 & 1.68 & 1.3 & 1.197 \\
\hline Arkis - HYD 2 & 4 & 23.52 & 1.68 & 1.3 & 2.448 \\
\hline Arkis - HYD 2 & 8 & 23.52 & 1.68 & 1.3 & 2.448 \\
\hline Arkis - HYD 2 & 15 & 23.52 & 1.68 & 1.3 & 2.448 \\
\hline Arkis - HYD 2 & 20 & 23.52 & 1.68 & 1.3 & 2.448 \\
\hline
\end{tabular}

In some of the existing studies, the experiments were carried out by using circular piers and the results were generalized for otherwise shaped piers by taking into consideration various shape factors. The shape factors suggested by different researchers including ([2]; [24]; [35]; 
[36]; [26]; [37]; [9]; [10]; [1]; [22]; [12]) are summarized in Table 14, together with those obtained from the experimental findings combined with the nonlinear regression analysis. The given coefficients concern the scenarios 1 and 2 which provided the highest coefficients of determination.
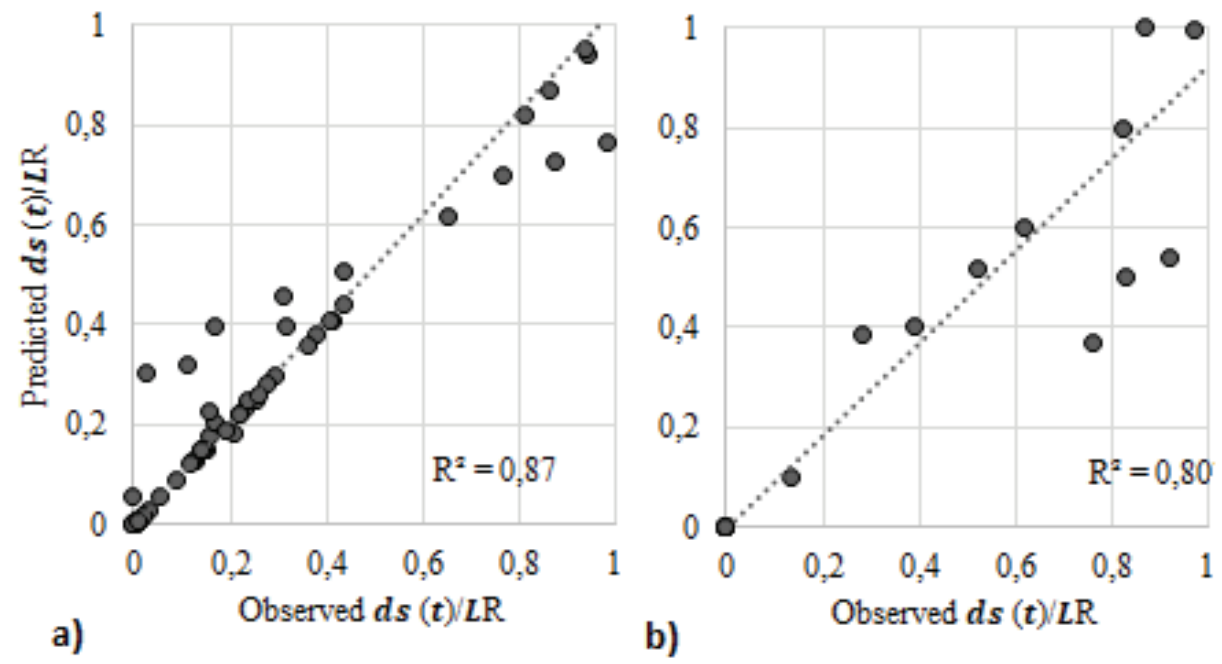

Figure 18 - Comparison of the dimensionless time dependent scour depth $d_{s}(t) / L_{R}$ computed from the suggested relation scenario 1 for P1 and those measured by a) [34] and b) [27]

Table 14 - Pier shape factor values Ks proposed by Researchers and those obtained in this study

\begin{tabular}{|c|c|c|c|c|c|c|c|c|c|c|c|c|c|}
\hline \multirow{2}{*}{$\begin{array}{l}\text { Pier } \\
\text { Type }\end{array}$} & \multirow[b]{2}{*}{ 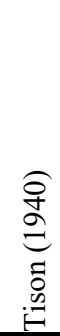 } & \multirow{2}{*}{ 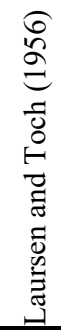 } & \multirow{2}{*}{ 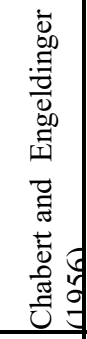 } & \multirow[b]{2}{*}{ 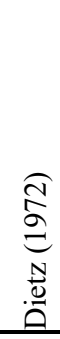 } & \multirow{2}{*}{ 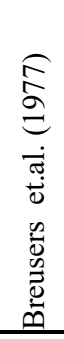 } & \multirow[b]{2}{*}{ 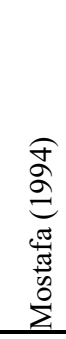 } & \multirow{2}{*}{ 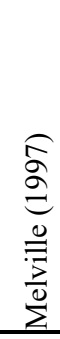 } & \multirow{2}{*}{ 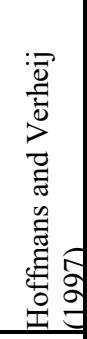 } & \multirow{2}{*}{ 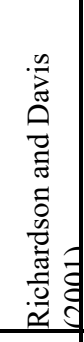 } & \multirow{2}{*}{ 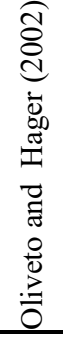 } & \multirow[b]{2}{*}{ 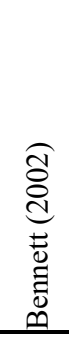 } & \multicolumn{2}{|c|}{$\begin{array}{l}\mathrm{Ks} \text { (Calc.) } \\
\text { (present } \\
\text { study) }\end{array}$} \\
\hline & & & & & & & & & & & & $\begin{array}{l}\mathrm{Sc} \\
1\end{array}$ & $\begin{array}{l}\text { Sc } \\
4\end{array}$ \\
\hline P1 & 1 & 0.9 & 1 & 1 & 1 & 1 & 1 & 1 & 1 & 1 & 1 & 1 & 1 \\
\hline P2 & - & - & - & - & 1.2 & - & 1.1 & - & - & 1.3 & - & 0.99 & 1.1 \\
\hline P3 & 1.4 & 1 & 1.1 & 1.1 & 1.3 & 1.3 & 1 & $1-1.2$ & 1.1 & 1.2 & 1.1 & 1.35 & 1.34 \\
\hline P4 & - & 0.9 & - & 0.9 & - & 1.1 & 1 & 0.9 & 1 & - & 0.9 & 0.87 & 0.86 \\
\hline P5 & - & - & - & - & - & - & - & - & - & - & - & 0.76 & 0.76 \\
\hline
\end{tabular}




\subsection{Temporal Evolution of the Scour Holes Geometry}

The scour hole measurements were performed both with data obtained from the camera and laser meter combined with Surfer software program and by using laser meter combined with AutoCAD drawings at the end of each experiment. Scour and deposition areas were drawn by means of the image processing technique by using the data of Video Camera 1 and then illustrated in AutoCAD. This process was performed for all piers and the results obtained for the circular pier are presented in Fig. 19, as an illustrative example.

The geometric characteristics of the scour holes around the piers are summarized in Table 15. The scour contours were found to be almost uniformly spaced. The shape of the scour hole around piers was approximately an inverted cone. For the pier placed along the channel axis, the scour contours were almost symmetrical with respect to the pier axis.

The surface area and volume of the scour hole around the bridge piers were computed using AutoCAD Civil 3D software based on the conic approximation method, by calculating the volume between two sectional areas. The two areas are being added along with the square root of their product and multiplied by a third of distance between the areas to determine the volume. Accordingly, in Fig. 20, the dimensionless surface area $A^{*}=\frac{A_{\text {scour }}}{A_{\text {pier }}}$ and dimensionless time $T=\frac{t}{t_{R}}$, were used. Variations of dimensionless area against dimensionless time are shown in Fig. 20 for each pier and for 5 different hydrographs. The scour hole evolution can be defined by means of a mathematical expression such as $A^{*}=$ $a T^{b}$, a and b being coefficients [38]. In this study the same form of relation was investigated, and so obtained values are plotted as $\mathrm{A}^{*}$ versus $\mathrm{T}$ in Fig. 20 . The so obtained coefficients a and $\mathrm{b}$ are given in Table 16.

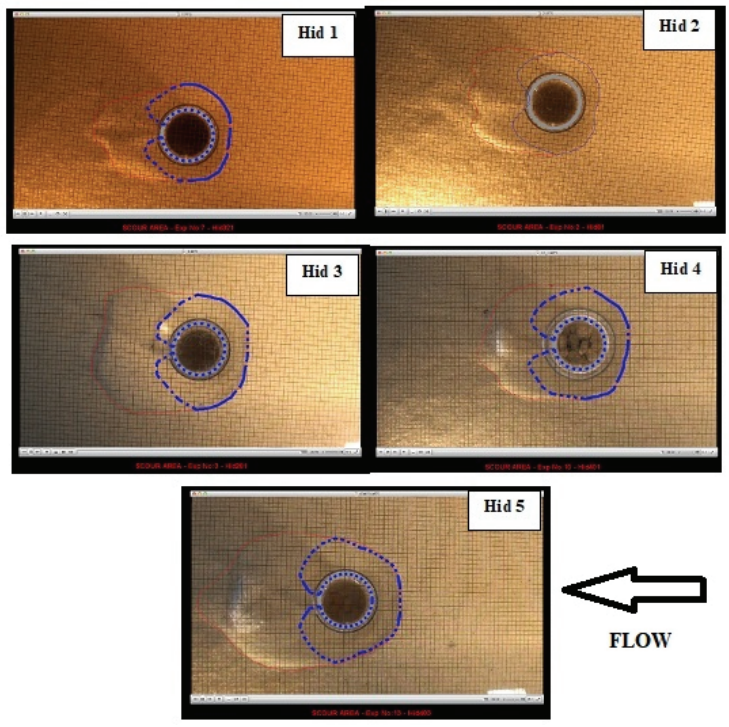

Figure 19 - Scour hole configuration for the circular pier after the image processing 
Table 15 - Scour hole measurements for piers

Pier ID Hyd. ID b (cm) $d_{\mathrm{sA}}(\mathrm{cm})$ Area $\left(\mathrm{cm}^{2}\right)$ Volume $\left(\mathrm{cm}^{3}\right)$

\begin{tabular}{llllll}
\hline & Hid 1 & 11 & 3.8 & 438 & 672 \\
P1 & Hid 2 & 11 & 5.8 & 472 & 977 \\
& Hid 3 & 11 & 5.8 & 501 & 1219 \\
& Hid 4 & 11 & 6.1 & 529 & 1028 \\
& Hid 5 & 11 & 6.5 & 563 & 1443 \\
\hline \multirow{4}{*}{ P2 } & Hid 1 & 8.5 & 4.1 & 402 & 435 \\
& Hid 2 & 8.5 & 6.6 & 420 & 785 \\
& Hid 3 & 8.5 & 7.6 & 601 & 1255 \\
& Hid 4 & 8.5 & 6.5 & 483 & 927 \\
& Hid 5 & 8.5 & 7.7 & 716 & 1459 \\
\hline & Hid 1 & 11.5 & 4.5 & 283 & 442 \\
& Hid 2 & 11.5 & 7.4 & 662 & 1447 \\
P3 & Hid 3 & 11.5 & 8.1 & 710 & 1819 \\
& Hid 4 & 11.5 & 7.8 & 602 & 1460 \\
& Hid 5 & 11.5 & 8 & 798 & 2006 \\
\hline & Hid 1 & 12 & 3.9 & 398 & 508 \\
& Hid 2 & 12 & 4.2 & 490 & 770 \\
P5 & Hid 3 & 12 & 5.5 & 512 & 928 \\
& Hid 4 & 12 & 4.4 & 537 & 942 \\
& Hid 5 & 12 & 5.4 & 586 & 1078 \\
\hline & Hid 1 & 11 & 2 & 289 & 211 \\
& Hid 2 & 11 & 3.7 & 420 & 595 \\
& Hid 4 & 11 & 4.2 & 446 & 644 \\
& Hid 5 & 11 & 5.2 & 569 & 755 \\
\hline
\end{tabular}


Experimental Investigation of Scour Hole Characteristics for Different Shapes of ...
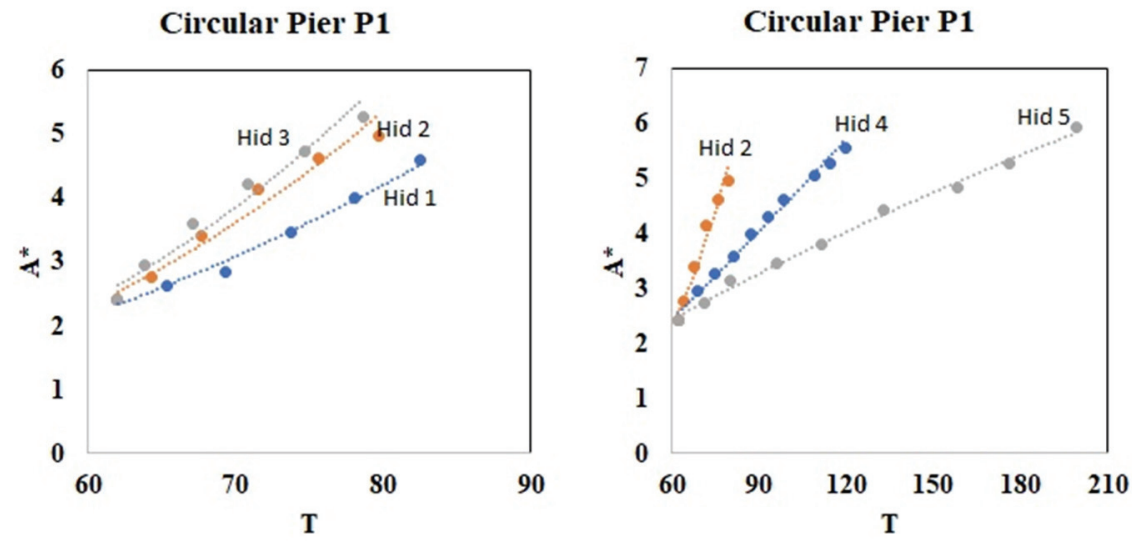

Square Pier P2

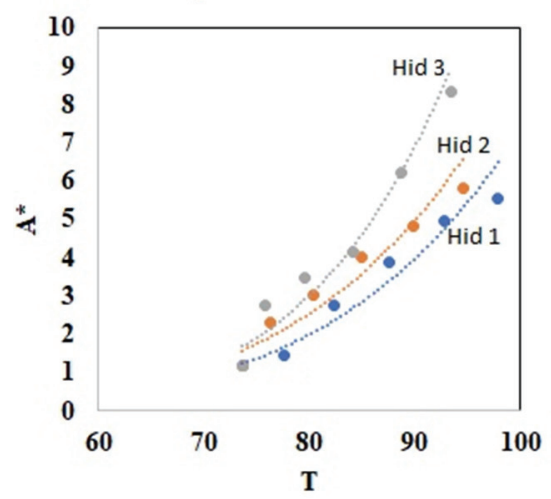

Square Pier P2
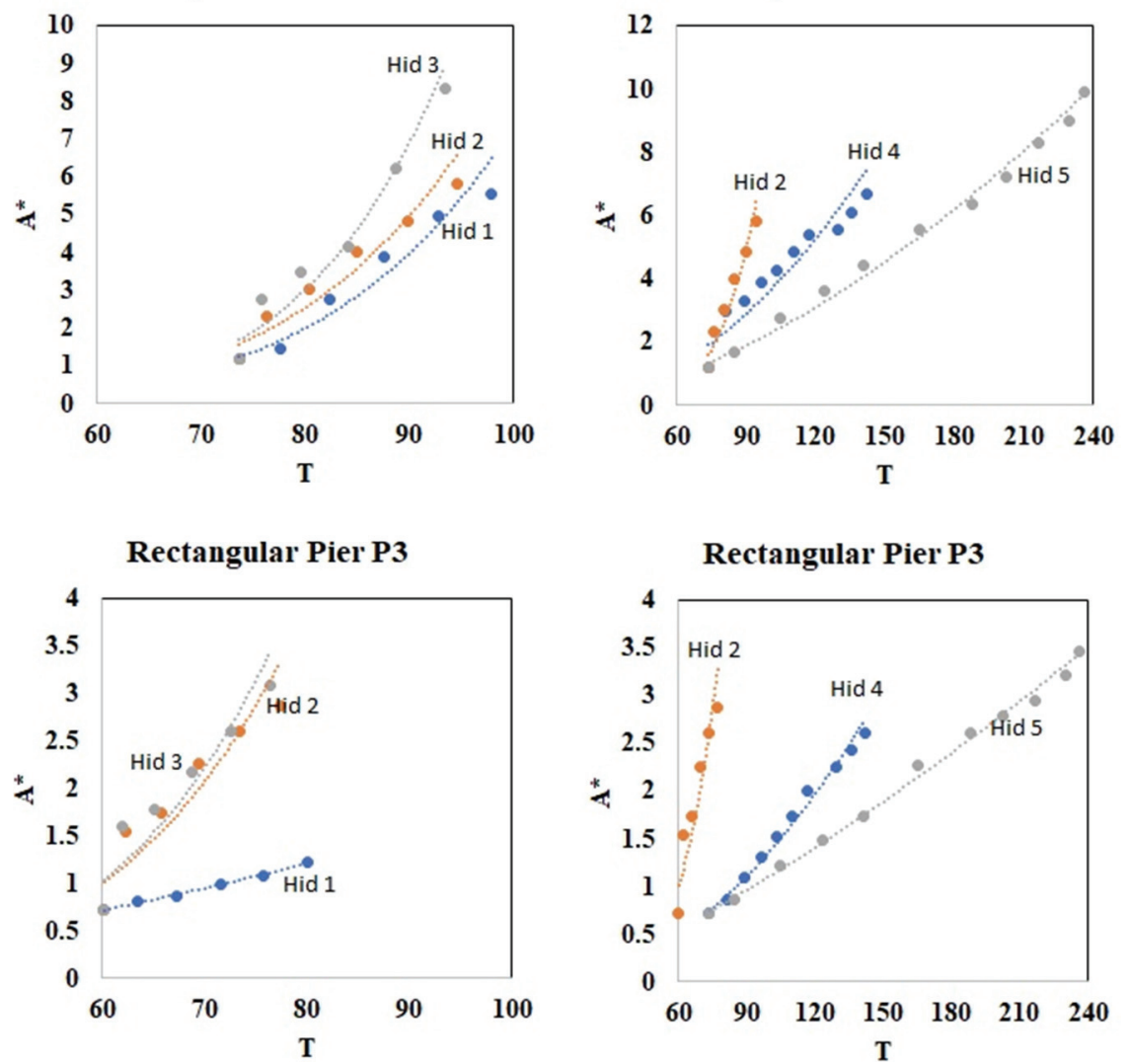

Figure 20 - Variation of $A^{*}$ with respect to $T$ 
Rectangular with circular nose

Pier P4

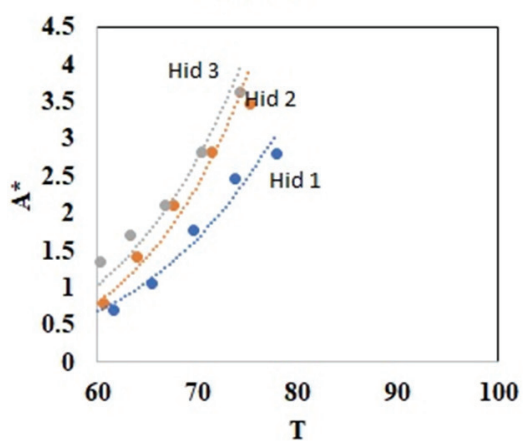

\section{Rectangular with trapezoidal} nose Pier P5

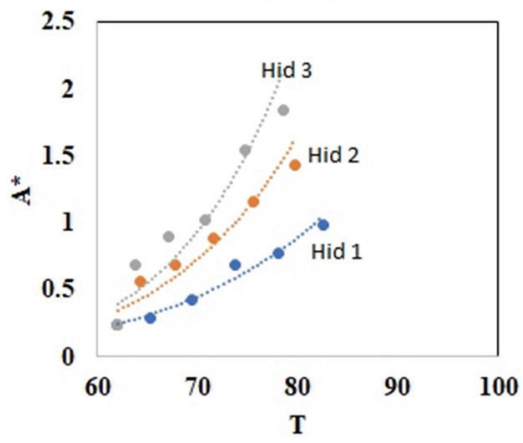

Rectangular with circular nose Pier P4

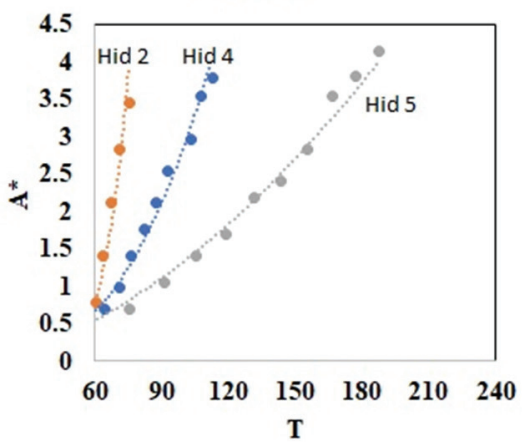

Rectangular with trapezoidal nose Pier P5

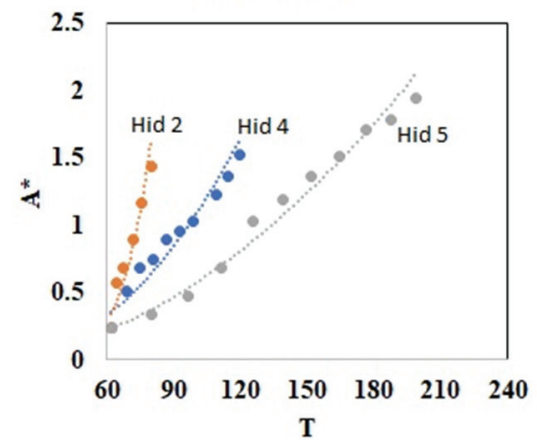

Figure 20 - Variation in $A^{*}$ with respect to $T$ (Continued)

Table 16 - Coefficients $a$ and $b$ of the mathematical expressions

\begin{tabular}{|l|l|l|l|l|l|l|}
\hline & & Hid55-45 & Hid55-63 & Hid55-73 & Hid1010-63 & Hid2020-63 \\
\hline \multirow{2}{*}{ P1 } & $\mathbf{a}$ & 0.0002 & $1 \times 10^{-5}$ & $6 \times 10^{-6}$ & 0.017 & 0.12 \\
\cline { 2 - 7 } & $\mathbf{b}$ & 2.31 & 2.94 & 3.14 & 1.22 & 0.73 \\
\hline \multirow{3}{*}{ P2 } & $\mathbf{a}$ & $2 \times 10^{-11}$ & $4 \times 10^{-11}$ & $1 \times 10^{-13}$ & 0.0003 & 0.0009 \\
\cline { 2 - 7 } & $\mathbf{b}$ & 5.83 & 5.7 & 7.02 & 2.07 & 1.7 \\
\hline \multirow{2}{*}{ P3 } & $\mathbf{a}$ & 0.0004 & $4 \times 10^{-9}$ & $1 \times 10^{-9}$ & 0.0001 & 0.0026 \\
\cline { 2 - 7 } & $\mathbf{b}$ & 1.83 & 4.72 & 5 & 1.99 & 1.32 \\
\hline \multirow{3}{*}{ P4 } & $\mathbf{a}$ & $4 \times 10^{-11}$ & $3 \times 10^{-13}$ & $7 \times 10^{-12}$ & $5 \times 10^{-6}$ & 0.0004 \\
\cline { 2 - 7 } & $\mathbf{b}$ & 5.77 & 7.02 & 6.23 & 2.89 & 1.74 \\
\hline \multirow{2}{*}{ P5 } & $\mathbf{a}$ & $2 \times 10^{-10}$ & $4 \times 10^{-12}$ & $7 \times 10^{-14}$ & $3 \times 10^{-5}$ & $9 \times 10^{-5}$ \\
\cline { 2 - 7 } & $\mathbf{b}$ & 5.12 & 6.13 & 7.1 & 2.31 & 1.9 \\
\hline
\end{tabular}




\section{CONCLUSIONS}

In this study, clear water scour experiments were performed for five different shapes of piers; circular, square, rectangular, rectangular with circular nose (lenticular) and rectangular with trapezoidal nose, for five triangular shaped hydrographs. It was revealed that there were substantial differences among the different scour holes related to the pier shapes and hydrograph characteristics.

- The peak flow rates were much more effective on the scour depths compared to the hydrograph durations. The scour depth evolutions were mainly influenced during the rising limb and the maximum scour depth occurred approximately at the peak flow rate, without significant change during the recession period of the hydrographs. It was observed from the experiments that about more than $90 \%$ of the maximum scour depth occurred initially for all pier shapes at about peak times of the experiments.

- From the inspection of Table 4, the maximum scour depth at measurement points A and B was found to be the smallest in the case of the pier P5. As shown in Table 4 the maximum scour depth at measurement point A was observed in the case of the pier P3.

- From the inspection of Table 5a, it was revealed that the pier P4 was affected least, while the pier P5 was influenced most. From the inspection of Table 5b, it was found that the pier P5 was influenced most from the fractional changes in the flow.

- There is a discrepancy between the measured dimensionless scour depths and those calculated from the relation suggested by [27]. The values calculated from this relation was found to be underestimated in all cases. The majority of the measured values and those calculated from the equation proposed by [33] were found to be in the interval of $\pm 25 \%$.

- The derived empirical relations concerning the time dependent dimensionless scour depths were studied statistically. The so obtained determination coefficients revealed that the most effective parameters were $F_{d}, I, \frac{h}{b}, \frac{b}{D_{50}}$ and $\mathrm{T}$.

- The regression analysis was performed to investigate the pier shape factor. As seen in Table 14 the average values are as follows: $\mathrm{K}_{\mathrm{s}}=1.045$ for the pier $\mathrm{P} 2, \mathrm{~K}_{\mathrm{s}}=1.345$ for the pier $\mathrm{P} 3$ and $\mathrm{K}_{\mathrm{s}}=0.865$ for the pier $\mathrm{P} 4$. These values are close to those existing in the literature.

- The pier shape factor in the case of the pier P5 (the rectangular shape with trapezoidal nose) was found to be equal to 0.760 .

- From the inspection of the Fig. 20 it was revealed that the geometry of the pier shape effects the scour hole development directly. The larger value of the ratio of the scour area to the pier area for different shaped piers are found to be as follows: for pier P1 $\mathrm{A}^{*}=5$, for pier P2 $\mathrm{A}^{*}=8$, for pier P3 $\mathrm{A}^{*}=3.5$, for pier P4 $\mathrm{A}^{*}=4$ and for pier P5 $\mathrm{A}^{*}=2$. 
- $\quad$ The empirical relation in the form $A^{*}=a T^{b}$ was found to be convenient to express the dimensionless scour hole surface area versus the dimensionless time.

- According to these results, the rectangle with trapezoidal nose shaped piers and the rectangle with circular nose shaped bridge piers were found to be more advantageous with respect to decrease in the magnitude of the scour depth.

- One can say that the volume of the scour hole depends on the cross section of the piers. Although the P4 (rectangular with circular nose) pier caused the largest scour depth, the scour hole with the smallest volume was observed for this pier.

- Similar investigations will be useful to exhibit the behavior of non-uniform sediment to reveal the influence of the sediment dimension and geometric standard deviation of particle size distribution. Various shaped hydrographs may also be generated in order to study the influence of the hydrograph shapes.

\section{Symbols}

$A=$ Scour hole area $\left(\mathrm{L}^{2}\right)$

$b=$ pier width (L)

$d_{s}=$ scour depth (L)

$D_{50}=$ median grain size $(\mathrm{L})$

$\mathrm{F}_{d}=$ densimetric particle Froude number

$\mathrm{F}_{r}=$ Froude number

$g=$ gravitational acceleration $\left(\mathrm{LT}^{-2}\right)$

$g^{\prime}=$ reduced gravitational acceleration $g^{\prime}=\left(\left(\rho_{s}-\rho\right) / \rho\right) g$

$h=$ approach flow depth (L)

$I=$ flow intensity ratio

$K_{s}=$ pier shape factor

$L_{R}=$ reference length

$n=$ hydrograph shape parameter

$Q=\operatorname{discharge}\left(\mathrm{L}^{3} / \mathrm{T}\right)$

$T=$ dimensionless time

$t=$ time (T)

$u=$ mean approach velocity $(\mathrm{L} / \mathrm{T})$

$u_{c}=$ mean approach critical velocity $(\mathrm{L} / \mathrm{T})$

$u *_{c}=$ critical shear velocity $(\mathrm{L} / \mathrm{T})$ 
$\rho=$ fluid density

$\rho_{s}=$ sediment density

$\sigma_{g}=$ geometric standard deviation of the particle size distribution

\section{Subscripts}

$b=$ base flow

$p=$ peakflow

$M=$ peak flow (Hager and Unger (2010))

\section{References}

[1] Hoffmans. G.J.C.M., Verheij. H.J., Scour Manual, Rotterdam, Netherlands, 1997

[2] Chabert. J., Engeldinger. P., Etude des affouillements autour des piles de ponts (Study of scouring around bridge piers). Chatou, France: Laboratoire National d'Hydraulique, 1956.

[3] Laursen. E., M, An analysis of relief bridge scour. American Society of Civil Engineers, Journal of the Hydraulics Division, 89 (HY3), 93-118, 1963.

[4] Shen, H. W., Schneider, V. R., Karaki, S. S., Local scour around bridge piers. American Society of Civil Engineers, Journal of the Hydraulics Division, 95 (HY6), 1969.

[5] Melville, B.W., Local scour at bridge sites. University of Auckland, School of Engineering, 1975.

[6] Ettema, R., Kirkil, G., Muste, M., Similitude of Large-Scale Turbulence in Experiments on Local Scour at Cylinders. Journal of Hydraulic Engineering 132:33-40. doi: 10.1061/(ASCE)0733-9429(2006)132:1(33), 2006.

[7] Yanmaz, A.M., Altinbilek, H.D., Study of time-dependent local scour around bridge piers. J. of Hydraulic Eng., Vol. 117, No. 10, 1991.

[8] Kothyari, U.C., Raju, K.G.R., Garde, R.J., Live-bed scour around cylindrical bridge piers. Journal of Hydraulic Research 30:701-715. doi: 10.1080/00221689209498889,1992.

[9] Richardson, E. V., Davis, S.R., Evaluating scour at bridges - Third edition. Hydraulic Engineering Circular No. 18, Federal Highway Administration Publication No. FHWA HI 96-031, Washington, D.C., 1995.

[10] Melville, B.W., Raudkivi, A.J., Effects of Foundation Geometry on Bridge Pier Scour. Journal of Hydraulic Engineering 122:203-209. doi: 10.1061/(ASCE)07339429(1996)122:4(203), 1996. 
[11] Melville, B.W., Chiew, Y.M., Time Scale for Local Scour at Bridge Piers. Journal of Hydraulic Engineering 125:59-65. doi: 10.1061/(ASCE)0733-9429(1999)125:1(59), 1999.

[12] Oliveto, G., Hager, W.H., Temporal Evolution of Clear-Water Pier and Abutment Scour. Journal of Hydraulic Engineering 128:811-820. doi: 10.1061/(ASCE)07339429(2002)128:9(811), 2002.

[13] Dey, S., Westrich, B., Hydraulics of Submerged Jet Subject to Change in Cohesive Bed Geometry. Journal of Hydraulic Engineering 129:44-53. doi: 10.1061/(ASCE)07339429(2003)129:1(44), 2003.

[14] Chang, W.Y., Lai, J.S., Yen, C.L., Evolution of Scour Depth at Circular Bridge Piers. Journal of Hydraulic Engineering 130:905-913. doi: 10.1061/(ASCE)07339429(2004)130:9(905), 2004.

[15] Köse, Ö., Experimental and analytical investigation of temporal variation of local scour at bridge abutments. Middle East Technical University, 2007.

[16] Diab, R., Experimental investigation on scouring around piers of different shape and alignement in gravel. Middle East Technical University, 2011.

[17] Guney, M.S., Bombar, G., Experimental Investigation of Time-Dependent Local Scour at Bridge Piers. In: River Corridor Restoration Conference. Switzerland, 2011.

[18] Mohammadpour, R., Ghani, A., Azamathulla, H.M., Prediction of equilibrium scour time around long abutments. Proceedings of the Institution of Civil Engineers - Water Management 166:394-401. doi: 10.1680/wama.11.00075, 2013.

[19] López, G., Teixeira, L., Ortega-Sánchez, M., Simarro, G., Estimating Final Scour Depth under Clear-Water Flood Waves. Journal of Hydraulic Engineering 140:328332. doi: 10.1061/(ASCE)HY.1943-7900.0000804, 2014.

[20] Hamidifar, H.M., Nasrabadi, M.H.O., Using a bed sill as a scour countermeasure downstream of an apron. Ain Shams Engineering Journal, 2011.

[21] Vijayasree, B.A., Eldho, T.I., Mazumder, B.S., Ahmad, N., Influence of bridge pier shape on flow field and scour geometry. International Journal of River Basin Management 17:109-129. doi: 10.1080/15715124.2017.1394315, 2019.

[22] Bennetts, T.A., Local scour around bridge piers under steady and unsteady flow conditions. University of Hertfordshire, 2002.

[23] Das, S., Ghosh, R., Das, R., Mazumdar, A., Clear water scour geometry around circular piers. Ecol. Environ. Conserv. 20(2), 479-492., 2014.

[24] Tison, L.J., Local scour in rivers. Journal of Geophysical Research (1896-1977) 66:4227-4232. doi: 10.1029/JZ066i012p04227, 1961.

[25] Cunha, L.V., Time evaluation of local scour. In: IAHR (ed) International Association for Hydraulic Research, Eleventh International Congress. Sao Paulo, 1975.

[26] Breusers, H.N.C., Nicollet, G., Shen, H.W., Local Scour Around Cylindrical Piers. Journal of Hydraulic Research 15:211-252. doi: 10.1080/00221687709499645, 1977. 
[27] Oliveto, G., Hager, W.H., Further Results to Time-Dependent Local Scour at Bridge Elements. Journal of Hydraulic Engineering 131:97-105. doi: 10.1061/(ASCE)07339429(2005)131:2(97), 2005.

[28] Dey, S., Fluvial Hydrodynamics.Springer, 2014.

[29] Bor, A.T., Experimental and Numerical Study of Local Scour Around Bridge Piers with Different Cross Sections Caused by Flood Hydrograph Succeeding Steady Flow. Dokuz Eylül University, 2015.

[30] Melville, B.W., Coleman, S.E., Bridge Scour. Water Resources Publications, Colorado,ABD, 2000.

[31] Lanca, R.M.M., Simarro, G., Fael, C.M.S., Cardoso, A.E., Effect of Viscosity on the Equilibrium Scour Depth at Single Cylindrical Piers. Journal of Hydraulic Engineering Vol.142 No:3 Pages: 06015022. doi: 10.1061/(ASCE)HY.1943-7900.0001102, 2016.

[32] Tsutsui, T., Fluid force acting on a cylindrical pier standing in a scour. In: Bluff Bodies Aerodynamics\& Applications. Milano Italy, 2008.

[33] Hager, W.H., Unger, J., Bridge Pier Scour under Flood Waves. Journal of Hydraulic Engineering 136:842-847. doi: 10.1061/(ASCE)HY.1943-7900.0000281, 2010.

[34] Arkis, A., Köprü Uç Ve Orta Ayaklari Etrafindaki Yerel Oyulmalara Karşi Koruyucu Önlemlerin Araştirilmasi. Dokuz Eylül University, 2013.

[35] Laursen, E.M., Toch, A., Scour around bridge piers and abutments, Iowa Highways Research Board, Ames, IA., 1956.

[36] Dietz, J., Construction of long piers at oblique currents illustrated by the BAB-Main Bridge Eddersheim, and Systematic model tests on scour formation at piers. Mitteilungsblatt der Bundersanstalt fur Wasserbau, Karlsruhe, Germany 31:79-109, 1972.

[37] Mostafa, E.A., Scour around skewed bridge piers. Alexandria University, Alexandria, Egypt, 1994.

[38] Yanmaz, A.M., Kose, O., Surface Characteristics of Scouring at Bridge Elements. Turkish J Eng Env Sci 31:127-134, 2007. 